\title{
The Image-Or from Whom (Not?) to Buy a Second-Hand Car
}

\section{o.1 The Portraits of Jacopo and Ottavio Strada}

In the summer of 2008 the Rijksmuseum in Amsterdam mounted a small exhibit showing Tintoretto's portrait of Ottavio Strada da Rosberg, antiquary to the Emperor Rudolf II, from its own collection [Fig. 0.2], next to Titian's famous portrait of Jacopo Strada, Ottavio's father and predecessor as antiquary to the Emperors Ferdinand I, Maximilian II and Rudolf II, which had been sent on loan by the Kunsthistorisches Museum in Vienna for the occasion [Fig. 0.1]. An occasion of some moment because it was the first time for at least three hundred and fifty years that these two portraits, which had been painted simultaneously in Venice in $1567-1568$, could be seen side by side.

Titian's portrait of Jacopo Strada has always been well known, having entered the Imperial collections already by the middle of the seventeenth
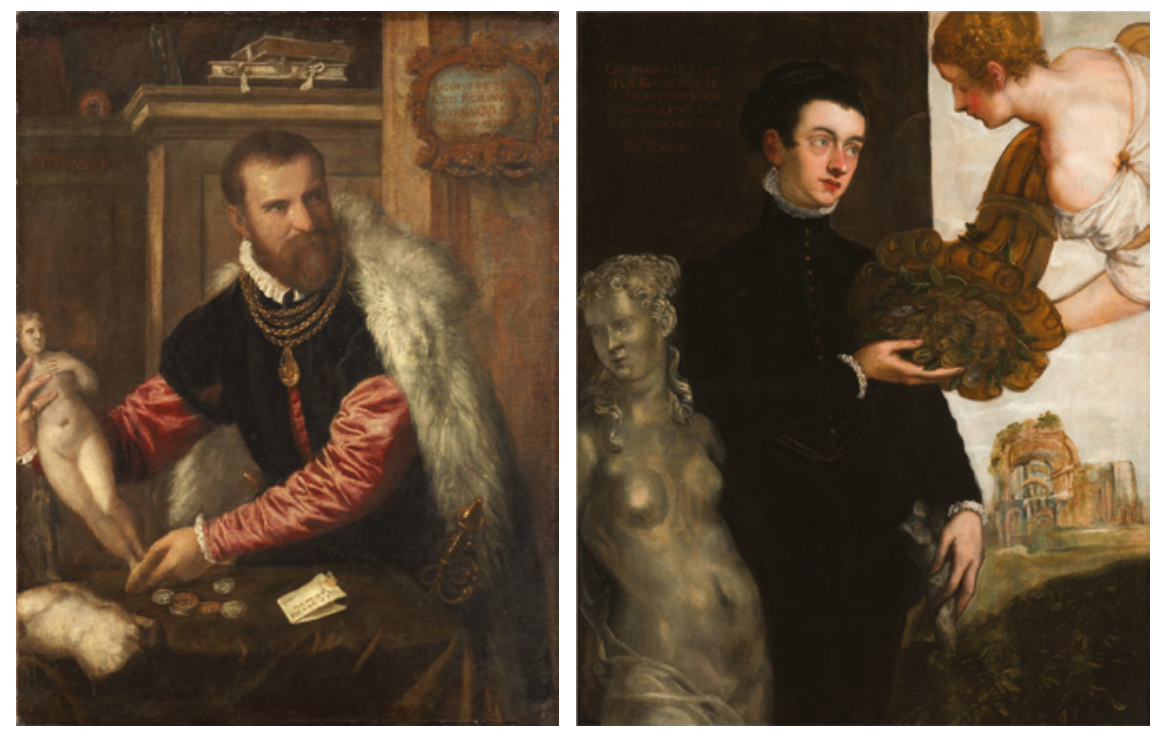

FIGURE 0.1 Tiziano Vecellio, Portrait of Jacopo Strada, Vienna, Kunsthistorisches Museum.

FIGURE 0.2 Jacopo Tintoretto, Portrait of Ottavio Strada da Rosberg, Amsterdam, Rijksmuseum. 

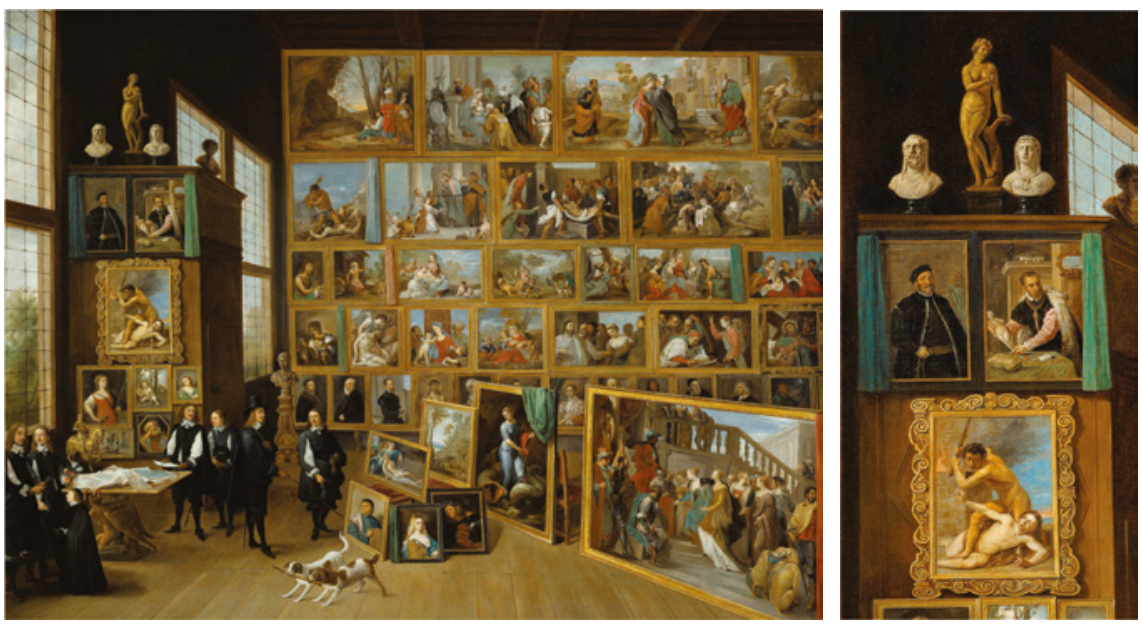

FIGURE 0.3 David Teniers the Younger, Archduke Leopold Wilhelm Visiting his Picture Gallery in Brussels, ca 1651, Vienna, Kunsthistorisches Museum. The portrait of Jacopo Strada can be seen top left near the window (detail), next to Titian's portrait of Fabrizio Salvaresi of $155^{8}$, which is likewise still preserved in the Kunsthistorisches Museum.

century, when it is listed in an inventory of the picture collection of Archduke Leopold Wilhelm of Austria, governor of the Southern Netherlands. It is shown in David Teniers' painting showing the Archduke paying a visit to his picture gallery in Brussels [Fig. 0.3 and detail]. Its attraction is attested by the inclusion of a reproduction engraved by Lucas Vorsterman the Younger in Teniers' Theatrum artis pictoriae, basically an illustrated inventory of the Archduke's collection printed in Brussels in 1660 [Fig. 0.5], and by a copy in oils from the late seventeenth century, which is attributed to Pietro della Vecchia [Fig. 0.4].1

The Jacopo Strada was probably Titian's very last portrait and is, for its iconography, an exceptional work within his oeuvre: as such it has often been studied and discussed. ${ }^{2}$ Tintoretto's portrait of Ottavio Strada, on the other hand, was virtually unknown until it entered the Rijksmuseum in 1956. It had earlier belonged to the Duke of Marlborough, who in turn had acquired it in the second half of the nineteenth century in France, perhaps directly from

1 By Federico Zeri; published in the catalogue of Armondi Antichità, Brescia:Antologia diMaestri Antichi 1990, cat. nr 14.

2 Most recently in the catalogue of the exhibition Rivalités à Venise, Paris, Louvre 2009-2010; cf. Bull 2009a; Crowe / Cavalcaselle 1877-1878, II, pp. 352-359; Zimmermann 19o1; PopeHennessy 1966, pp, 145-146; Panofsky 1969, pp. 79-81; Wethey 1969-1975, 2, p. 48-49 and cat. nr. 100, pp. 141-142; Mucchi 1977, pp. 302-304; Hope 1979, pp. 7-10; Freedman 1999; Gentili 2005, pp. 54-56; Ferino-Pagden 2008, cat. nr 1.13. 

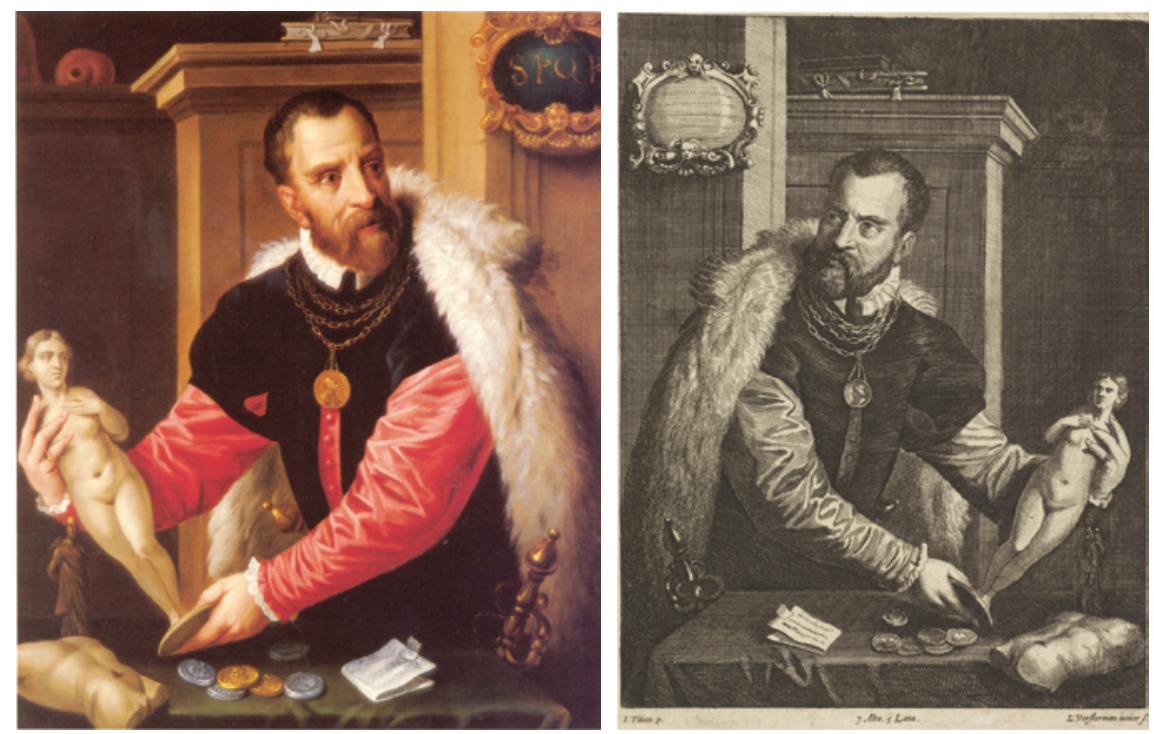

FIgURE 0.4 Attributed to Pietro della Vecchia, after Titian, Portrait of Jacopo Strada; present location unknown.

FIGURE 0.5 Lucas Vorsterman the Younger, engraving after Titian, Portrait of Jacopo Strada, from Theatrum artis pictoriae, Brussels 1660.

Robert, Marquis de Strada d'Arosberg, the lineal descendant of both sitters, who had an English wife. In the Marlborough collection the Tintoretto was accessible only to a restricted audience. In the Rijksmuseum, which concentrates primarily on Dutch painting, though more easily accessible, it has perhaps received less attention than it might have in the Louvre or the National Gallery, and certainly much less than it deserves. It is satisfying that this relative neglect has been splendidly redressed by the felicitous cleaning and restoration of the Tintoretto, and by the temporary reunion of the two portraits first in the Rijksmuseum, and then in the exhibition on Venetian Painting of the sixteenth century at the Louvre. ${ }^{3}$

Though the present study attempts to show that Jacopo Strada is a sufficiently interesting personality to warrant some attention in his own right, there is little doubt that his chief claim to fame remains the portrait- - a fact of which he himself may have been very well aware. Certainly his later reputation has been coloured by the image projected by Titian's masterpiece. A summary of its reception and of the image of Strada's personality it helped foster is a

3 Rivalités à Venise, Paris, Louvre 2009-2010; cf. Bull 2009a; I am grateful to Duncan Bull and Willem de Ridder for allowing me to see Ottavio's portrait during cleaning and for a stimulating discussion of the two portraits and their relationship. 
convenient point of departure for the fuller discussion of his career which is the subject of this book.

\section{o.2 Why are These Portraits so Special?}

Certainly Titian's and Tintoretto's portraits of the two Stradas merit a discussion in themselves: they are both splendid paintings, the work of two of the greatest painters of the Italian Renaissance. They are painters, moreover, who count among the founders of the portrait genre, and who had a tremendous influence on its later development, especially on Rubens and Van Dyck. But though that makes these paintings valuable and worthwhile as works of art, their unique significance for the history of art derives from a number of aspects that distinguish them from many other Renaissance portraits:

- The first of these is that both paintings have an exceptional place within the oeuvres of their respective painters, especially the Titian.

- At least equally important is the context in which the paintings were commissioned, which is much better known than is usual: whereas so many of the portraits of private citizens of the period are anonymous, here the identity of the sitters is undisputed. In fact we know quite a lot about them, and in particular about their activities at the time the portraits were painted.

- This context is also unusual in itself: except for portraits of married couples, it is quite exceptional to have two portraits painted in conjunction, as was the case here; that they were painted simultaneously by two more or less competing rivals is probably without parallel.

Finally, for both art-historians and art dealers the portraits are of particular interest, because the two sitters are in some way early examples of their own profession. Both Stradas presented themselves formally as 'antiquarius'. In English this can be translated either as 'antiquary' - that is someone studying the material remains of Antiquity, whom we would call an archaeologist or historian - or as 'antiquarian', an expert and dealer in art and antiques. In this study I hope to show that both terms are appropriate for the Stradas.

\subsection{Motions of the Mind}

The portrait of Jacopo Strada certainly occupies an exceptional place within Titian's oeuvre: it is one of the last—probably the very last—portrait he ever painted, and he had really stopped accepting portrait commissions much earlier. Compared with his earlier portraits, its formal qualities are unusual: whereas in general Titian's sitters maintain a quiet, dignified attitude against 
the habitual neutral or landscape background, here the protagonist is placed in a localized inner space, in a diagonal movement across the plane of the painting, actively inviting the observer to participate. The painting is moreover atypically crowded with attributes. So it is not surprising that the portrait has been often discussed in detail, mostly within the context of Titian's late style.

A principal reason why Titian's portrait of Jacopo Strada has received so much critical attention is that it is often considered as a prime example of Titian's gift of psychological penetration. In his book Portraits of the Renaissance John Pope-Hennessy discusses it as such in a chapter entitled 'The Motions of the Mind', a title he borrowed from one of Leonardo da Vinci's notebooks. He discusses the Strada portrait in prose sufficiently magnificent to be quoted in full:

To judge from the paintings he produced, Titian was gifted with a godlike view of the potentials of character and mind against which the individual before him was sized up. On only one occasion is his private reaction to a sitter set down in print. The victim was Jacopo Strada, a dealer in antiques, who was born at Mantua, allied himself with the Fuggers of Augsburg, joined the court of the Emperor Maximilian II, and in 1567 visited Venice in search of antiques for Albert, Duke of Bavaria.

Titian, who had known him for some years, viewed him with unfeigned dislike. A pretentious humbug, he called him, one of the most solemn ignoramuses that you could find. His success, Titian declared, was due to a capacity for flattery, and to the 'tante carotte' he had held out to the Germans, who were too dense to realize his incompetence and his duplicity.

In the painting Strada is shown bending obsequiously across a table, holding a marble statuette which he is displaying deferentially to some patron on the right. The significance of this motif would have been even more apparent than it is today when the picture was still free of the pompous cartouche in the upper right-hand corner which was added at Strada's own request.

The fur and sleeve are some of the most splendid passages in any Titian portrait $<\ldots>$ but the features contrast with the splendour of dress; they are petty, and are stamped with guile and a particularly unattractive sort of eagerness. And there is no reason to suppose that the effect was anything but calculated. ${ }^{4}$

'To judge from the paintings he produced, Titian was gifted with a godlike view of the potentials of character and mind against which the individual before

4 Pope-Hennessy 1966, pp. $145^{-147 .}$ 
him was sized up' This idea that a good portrait painter is able to fathom the deeper psychology, perhaps even the subconscious of his sitter, I find a highly fascinating, but also a very questionable assumption. I have tried to test this assumption many years ago, when I gave a talk on the Strada portrait to a class of second-year students of art-history at Leiden University. Before I had told them anything at all about the sitter, I asked the students to write down what they thought his character would have been like, just by looking at his portrait. I had given them a hand-out with the following three questions:

- What do you think about the social status of the person depicted in this portrait, and do you have any idea what might be his profession?

- Do you think that it is possible on the basis of this portrait to determine specific traits of character of the sitter, both positive and negative, and if so, which ones? (e.g. was he generous or grasping, smart or stupid, truthful or devious, corrupt or honest, and so on).

- Do you think the portrait provides any indication about the personal relationship between the sitter and the artist?

In the interval of the lecture I totted up the response of the fourteen students, and we discussed its outcome, which was quite interesting. It certainly corresponded but little with Pope-Hennessy's reading of the portrait. As could be expected, all respondents thought the painting portrayed someone of high social status, which is an obvious purpose of this, as it is of the majority of formal portraits. More interesting was the response to the second question: only two respondents did not think it possible to conclude anything about the character of the sitter from a painting such as this. In the light of PopeHennessy's negative judgment, it is more surprising that only one respondent expressed a similar negative view. The other twelve respondents all felt that the painting intended to convey a positive image of the sitter, defining his character in terms such as 'open-minded', 'a dry sense of humour', 'smart', 'strict but just', 'ambitious, dynamic, noble', 'energetic', 'cheerful', 'resolute, knows what he wants', 'observant', 'loves beautiful things', 'self-assured, vain, but not excessively conceited', 'well-educated', 'reads a lot, erudite'.

The response to the last question was rather evenly divided: about one half of the students thought that there was no particularly close relationship between painter and sitter, i.e. they considered Titian's attitude to be a purely professional one; some of them even found the portrait rather impersonal; while the others did presuppose some sort of personal relationship between painter and model, as close acquaintances or colleagues or as friends, one of them even presupposing that the painter admired his model. Only one respondent thought Titian might not really have liked his 'pretentious, showy' sitter.

Obviously this test was not intended as serious research into the reception of sixteenth-century portraiture, but I do think it shows how easily one 


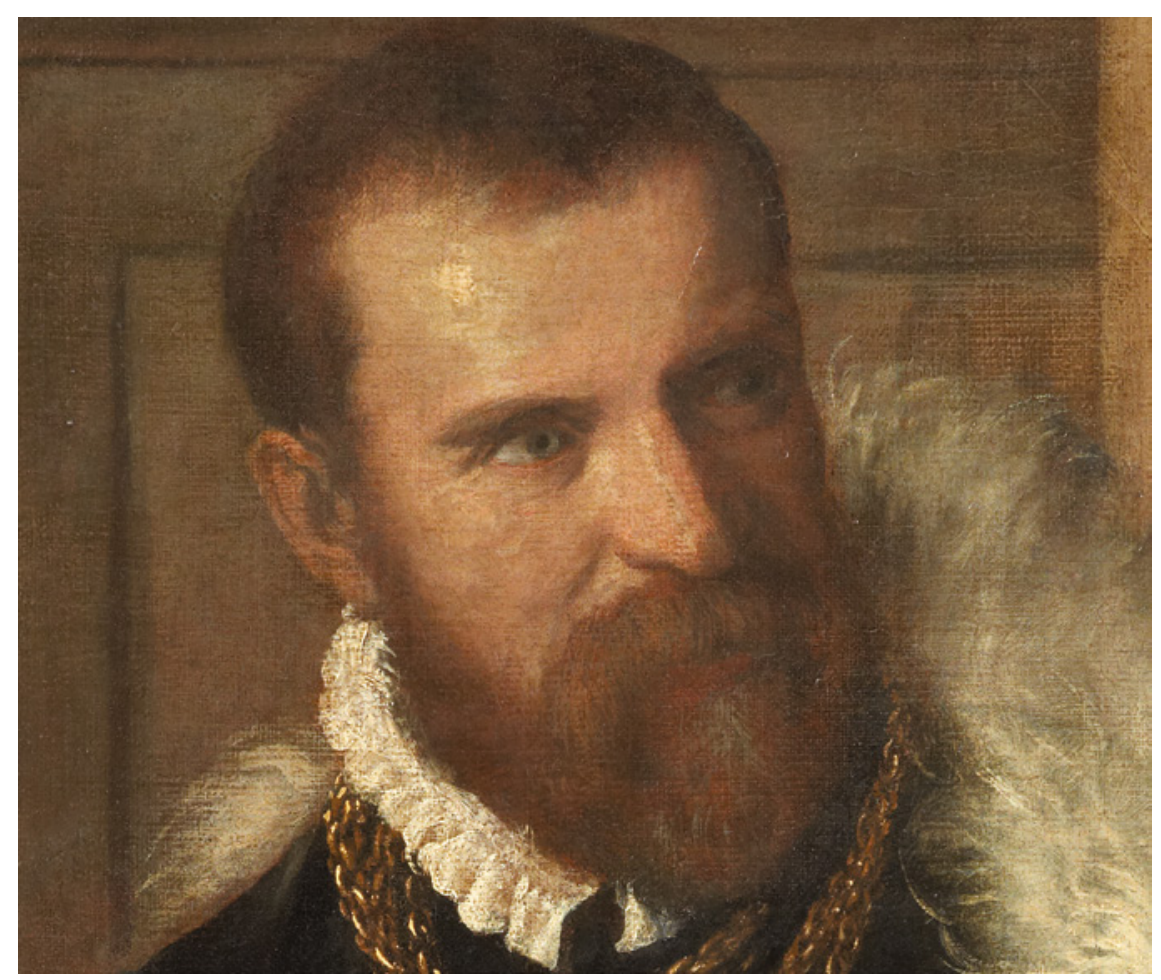

FIGURE 0.6 Titian, Portrait ofJacopo Strada, detail of fig o.1.

is tempted to draw objective conclusions from subjective impressions: a legitimate procedure as long as one is an art-lover appreciating a great work of art-as is the case of Pope-Hennessy's wonderful book-but inadmissible in a context of historical research. My own hypothesis is that, though good portraitists certainly do in fact manage to convey a psychologically convincing image of the character of their sitter, it does not necessarily follow thathowever convincing - it is either true or just. In any case the interpretation of that character remains very much in the eye of the beholder.

My own personal-and therefore subjective-impression is that in his Strada portrait Titian was far less interested in the deeper internal 'motions of the mind' of his sitter than he had been when he painted, for instance, The Man with the Glove, the Young Englishman of the Galleria Palatina, or his two 1548 portraits of Charles v. Certainly I think that Pope-Hennessy's reading was equally subjective: Titian's repugnance of his sitter Pope-Hennessy thought he saw reflected in the painting was merely the projection of his own patrician dislike for the upstart tradesman he imagined Strada to be on the basis of the documentary evidence he quotes. 
His source is the correspondence of Niccolò Stopio, a neo-Latin poet resident in Venice at the time, and — like Strada—engaged in the trade of art and antiques. Excerpts of Stopio's correspondence, which is preserved in the Bavarian State Archives in Munich, had been published already in 1874 by Jacob Stockbauer in a study of the artistic patronage of Duke Albrecht $\mathrm{V}$ of Bavaria, patron of both Strada and Stopio. Four years later it entered the Titian bibliography through the use made of Stopio's correspondence in Crowe and Cavalcaselle's huge monograph on the painter, first printed in Florence $1877-78 .{ }^{5}$ Stopio's original correspondence was sent on loan to Vienna to be used by Heinrich Zimmermann, who was preparing a biography of Strada which has never appeared. He did, however, write a carefully considered article on the exact dating of the portrait, in which Stopio's letters are likewise quoted extensively. ${ }^{6}$ But these letters led neither Crowe and Cavalcaselle nor Zimmermann to negative conclusions similar to those of Pope-Hennessy's. These were closely echoed, on the other hand, by a more recent discussion of the portrait by Augusto Gentili, under the heading 'Comprereste un'auto usato da quest'uomo?' This led a reviewer to characterize Strada more or less as the sixteenth-century equivalent of a mafia boss: 'In Titian's portraits it is not always the fine coat that makes the fine gentleman, and Jacopo Strada's very 'chic' air does not mask his greedy eyes, which certainly do not make one eager 'to buy a used car from the man'; conveniently forgetting that mafiosi of our own time rarely have their likeness taken by the greatest living portrait-painter. ${ }^{7}$

This interpretation of Strada's character, based on an uncritical acceptance of Stopio's letters, does not do justice to Strada, and moreover throws no light on Titian's decision to paint his portrait, and to paint it in this way. In my examination of Strada's career I will have occasion for a close reading of Stopio's reports, placing them within the context in which they were written. This will, I hope, provide a more balanced view of Jacopo Strada's true character and of his relationship with Titian.

5 Stockbauer 1874, pp. 29-52 (Strada), 53-69 (Stopio) and passim; Crowe /Cavalcaselle 18771878, II, pp. 353-359.

6 Zimmermann 1901.

7 BICCI 2006, review of GENTILI 2005: "Agile e gustoso il saggio che Gentili dedica alla ritrattistica tizianesca, capace di far emergere oltre l'apparenza sottili caratterizzazioni psicologiche. Nei ritratti di Tiziano l'abito non sempre fa il monaco e l'aria molto chic di Jacopo Strada non maschera il suo sguardo avido, che certo non invoglia a 'comprare un'auto usata da quest'uomo"'. Gentili had actually written (pp. 55-56): “<...> consegnando allimmagine il gesto pressante, il mezzo inchino ossequioso, lo sguardo rapace; e risolvendo nella vanitas $<\ldots>$ le frenetiche attività del mercante e le effimere presunzioni del cortigiano. La statua di Venere diventa un semplice oggetto di commercio; l'antiquario, uno scaltro venditore; lo spettatore, un possibile acquirente". 


\subsection{What is Known About Strada: Early Notices}

When setting out on my research into the man behind the portrait, forty years ago, I soon found out that the Titian portrait is indeed Strada's major claim to fame. His existence apart from it received little attention before the second half of the twentieth century; and if so, it was mostly in the form of brief notices throwing light on a specific aspect of his various activities. Yet, though the portrait was accessible through Vorsterman's engraving, the very earliest references on Strada rarely-if ever-refer to it. ${ }^{8}$ These entries were written by antiquarian scholars who used Strada's books, or by archivists and librarians who in their collection stumbled upon a manuscript by or a document relating to Strada that happened to interest them.

\subsubsection{Numismatics}

Strada's numismatic work was his principal contribution to the Republic of Letters, and it is mostly as a numismatist that he is referred to in the learned products of the Republic of Letters of the seventeenth and early eighteenth century. The earliest mentions are mostly bibliographical references to his printed books included in numismatic treatises, such as Antoine Le Pois' Discours sur les medalles et graveures antiques and a new, much expanded edition of Conrad Gesner's universal bibliography edited by two Zürich scholars, Josias Simler and Johannes Jacobus Frisius. ${ }^{9}$ Adolf Occo, another and better known numismatist of these years, does not refer to Strada's printed books in his own

8 This is less surprising than it seems: though Vorsterman's plate shows the cartouche, it does not render the inscription, and he omits to identify the sitter otherwise.

9 Le Pois 1579 fols. 2-3; on Le Pois' judgment of Strada and other contemporary numismatists, see Cooper 1990, pp. 14-15; Frisius 1583, p. 386 prepared his descriptions on the basis of copies in the Imperial library in Vienna, and included all the books published by Strada except his Frankfurt 1575 edition of Caesar's Commentaries. He added the curious but probably mistaken contention that Strada would have written "Scholia in Pontani librum De Immanitate". If Frisius got his information directly from Strada himself, as is perfectly possible, there must be some foundation to his contention, which is repeated once or twice in later reference works (Johann Albert Fabricius' Bibliographia antiquaria and Jöcher's Gelehrtenlexikon; cf. below). But I have not been able to find any publication or other reference corroborating this. Though it cannot be excluded that Strada, specializing in Roman imperial biographies, would have used and commented on Pontanus, I rather suspect that a note on Jacob Spiegel may have strayed among Frisius' filing-cards on Strada. In Jöcher's Gelehrtenlexikon, in which the entry on Strada repeats Frisius' contention (Jöcher 1750-1751, IV, col. 864; see below), Spiegel's cited publications include: "Scholia in Rich. Bartolini Austriados, s. De bello Norico libros xii, die auch unter Just. Reuberi scriptoribus; notae in Jo. Jov. Pontani De immunitate [sic]". The book in question is Giovanni Gioviano Pontano, De Immanitate Liber Unus, Cum Scholiis Iacobi Spiegel (Augsburg 1519) (Jöcher 1750-1751, IV, col. 736). 
treatise, but he did comment on Strada's drawings in a letter to his learned colleague Basilius Amerbach the Younger. Occo had admired the richly bound volumes of numismatic drawings that Strada had provided to Duke Albrecht $\mathrm{V}$ of Bavaria, and reports the fabulous price of a ducat that Strada was paid for each of these splendid drawings. Though Occo is sceptical about the veracity of many of the drawings, he yet deems it a precious treasure, truly befitting a prince. $^{10}$

Strada had made the huge folio volumes of numismatic drawings commended by Occo for the Emperors Ferdinand I and Maximilian II - these were preserved in the Imperial library in Vienna - and for Hans Jakob Fugger and Duke Albrecht $v$ of Bavaria: these later ended up as spoils of war in the library of Duke Ernest the Pious of Saxe-Gotha-Altenburg at Gotha. In both places they excited the interest of the officials locally responsible, such as the learned statesman Veit Ludwig von Seckendorf. Appointed librarian at Gotha in 1654, when he was hardly twenty years old, he had meanwhile been promoted to Privy Councillor of the Duchy. In a letter to Johann Andreas Bosius of 5 December 1657 he gave a summary description of Strada's volumes, of which the Duke had given him the first three to study, and added some critical notes on their contents. This letter became publicly known only in 1714, when it was transcribed in its entirety in the catalogue entry for the Strada manuscripts in Ernst Salomon Cyprian's Catalogus Codicum manuscriptum Bibliothecae Gothanae, together with a full transcription of Strada's preface annexed to one of the Gotha volumes."

The related volumes of Strada's numismatic drawings preserved in the Imperial Library in Vienna were of easier access than those in Gotha. In his travel diary Charles Patin [Fig. o.9] relates how he once had been received by Emperor Leopold I [Fig. 0.7], who had allowed him free access to the Imperial Library where, among its inexhaustible treasures, he had particularly admired

$10 \quad$ Quoted in Patin 1683, pp. 188-189. Occo's own treatise, Impp. Romanorum nvmismata a Pompeio Magno ad Heraclivm, was printed in Antwerp by Plantin in 1579 (occo 1579). Other references and comments to Strada's printed numismatic books crop up in several specialized bibliographies, such as the Bibliotheca nummaria by the Jesuit Philippe Labbé, first published in 1664. However, Labbé created a bibliographical 'ghost': a 'Thesaurum antiquitatum, sive imperatorum romanorum orientalium et occidentalium Icones ex antiquis numismatibus delineatae absque aversis illorum partibus, Lugduni anno 1551, in $4^{0}$, of which no copy has ever been found. It seems likely that he either quoted from a copyright privilege or from the title page of a lost manuscript (Labbe 1675).

11 Cyprian 1714, cat. nrs. 239-263, pp. 83-87; he also included verbatim a passage describing these volumes in Burckhard Struve's Introductio ad notitiam rei litterariae et usum bibliothecarum [Struve 1704, pp. 13-14], and gives the title of a ms. by Ottavio Strada [Cyprian 1714 , cat. nr 178, p. 75$]$. 
Jacopo and Ottavio's numismatic drawings: 'I went through the incomparable drawings of I. Strada, which one cannot see without becoming both more inquisitive and more learned. ${ }^{2}$

Patin's guide was Peter Lambeck, the Imperial librarian [Fig. 0.8], whose interest in the Strada manuscripts may have been stimulated by Patin's enthusiasm. Indirectly this interest was influenced by the Emperor himself: intrigued by the gift of a copy of Patin's new Paris edition of Fulvio Orsini and Antonio Agustín's De familiis Romanis, which was largely based on numismatic evidence, Leopold asked Lambeck to inspect the Imperial coin collection. The result of this was that numismatic material looms large in the huge volumes Lambeck dedicated to the history and holdings of the Imperial Library, his Commentariorum de augustissima Bibliotheca Caesarea Vindobonensi, the first volume of which was published in 1665 .

Chief among the works described were 'two volumes of manuscript in folio of the greatest value $<\ldots>$ exclusively dedicated to the Consular coins, drawn with incredible study and elegance from the originals, and that were presented to Emperor Ferdinand I by the most famous Imperial antiquary, Jacopo Strada from Mantua'. ${ }^{13}$ Lambeck not merely praised the detailed drawings contained in these volumes, but repeatedly referred to them in his learned arguments and also included several large engravings directly derived from them. ${ }^{14}$ The first of these is a consular coin and its reverse attributed to C. Petilius [Fig. 0.10]: in his comment on this coin Lambeck gives a brief survey of all of Strada's numismatic manuscripts among the Vienna holdings. Elsewhere he illustrates a coin attributed to P. Papirius Carbonus and a coin of Livia with engravings derived from Strada's drawings, and uses other ones to discuss the place of the cult of Vesta in Roman Antiquity.

Most interesting is his use of Strada's drawing of a Hadrianic coin dedicated to Antinous [Fig. 0.11] and of Strada's description of it, which he transcribed in extenso, in an attempt to interpret the most important antique find in the

12 Patin 1674, p. 226: 'J'y parcourus ces desseins incomparables de I. Strada, qu'on ne peut voir sans devenir et plus curieux et plus savant'; ibidem, p. 12: 'I'en vis aussi d'Octavius Strada en matiere de Médailles, avec une infinité de desseins de Raphaël, de Rubens, d'Albert, Durer et d'autres excellens Maîtres'. Elsewhere [Patin 1695, pp. 201-203] he refers to the printed numismatic works of Jacopo-'dont la lecture est absolument necessaire aux Historiens et aux Curieux' - and to those of Ottavio Strada, Jacopo's second son and successor, which were largely based on the researches of his father. Though Patin commended these works, he warned the reader that they contained 'un grand nombre de fausses particularitez, qu'il ne se faut pas engager à le croire sans beaucoup de discrétion'.

13 Lambeck 1665-1679, I, pp. 74-75.

14 Lambeck 1665-1679, I, pp. 76-78; I, p. 84; II (1669), p. 524; p. 739 (and accompanying engravings). 

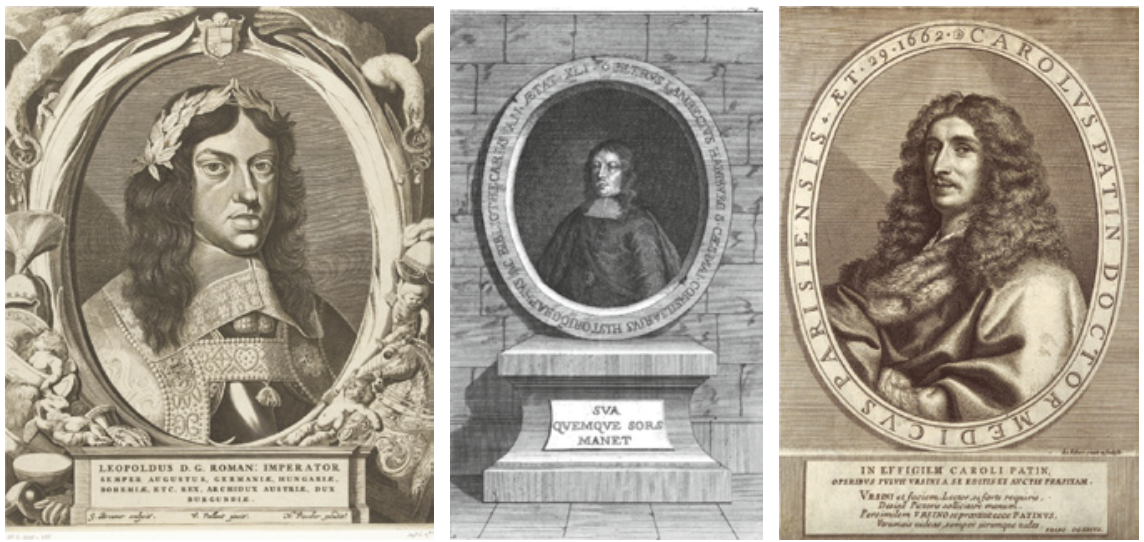

FIGURE 0.7 Emperor Leopold I (1640-1705), engraving by Jan Brouwer after Wallerant Vaillant.

FIGURE 0.8 Peter Lambeck (1628-1680), the Imperial librarian, engraving from his

Commentariorum de augustissima bibliotheca ceasarea Vindobonensis, 2nd ed., 1, Vienna 1766.

FIGURE 0.9 The French physician and scholar Charles Patin (1633-1693), engraving by C. Le Febure.

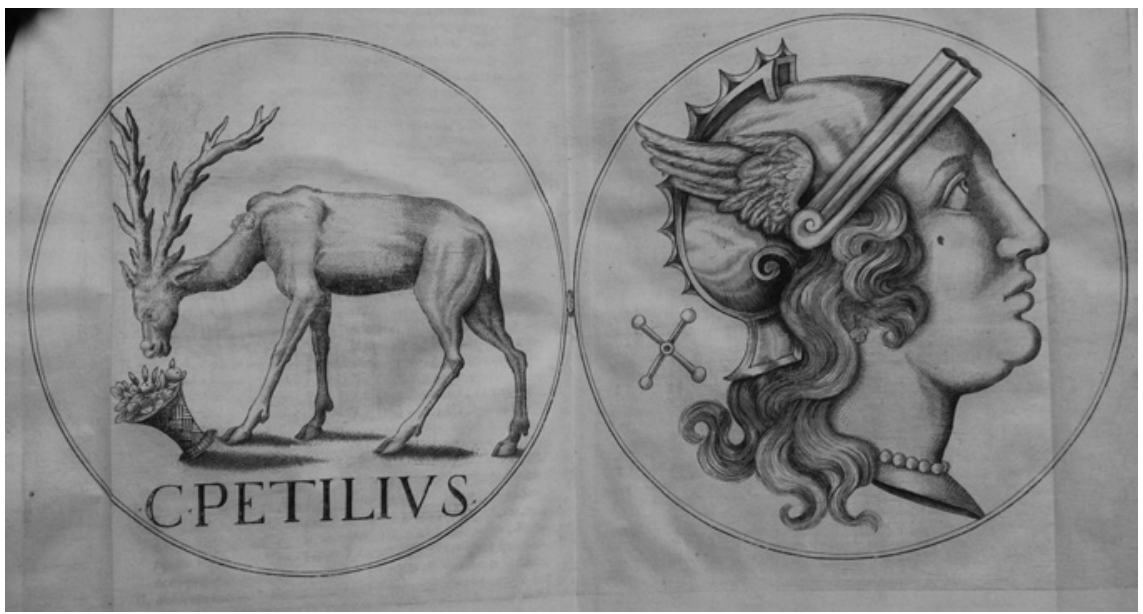

FIGURE 0.10 Engraving after a numismatic drawing by Jacopo Strada, in Lambeck's Commentariorum de Augustussima Bibliotheca Caesarea, I (1665).

Austrian Erblande ever, the famous bronze ephebe that in 1502 was excavated at the Helenenberg near Klagenfurt (now confusingly known as the 'Jüngling vom Magdalensberg') [Fig. 0.12].15

15 Lambeck 1665-1679, II (1669), pp. 684-685 (and accompanying engraving). The statue is nowadays only known from a Renaissance bronze cast in the Kunsthistorisches Museum 

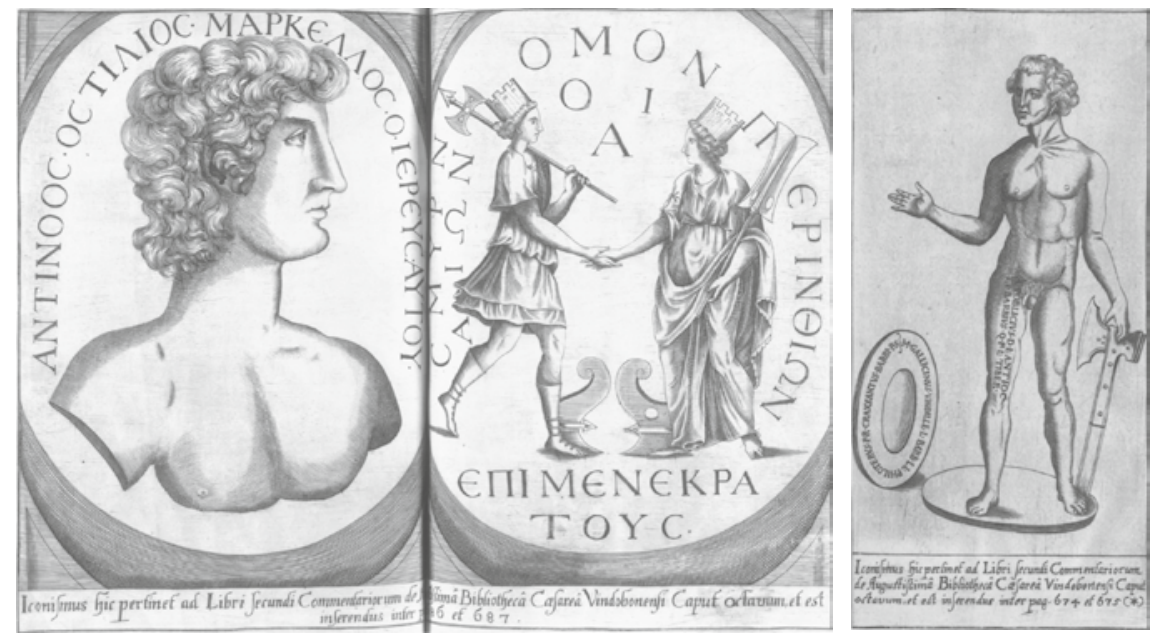

FIGURE 0.11 Engraving after a numismatic drawing by Jacopo Strada, in Lambeck's Commentariorum de Augustussima Bibliotheca Caesarea, II (1669).

FIGURE 0.12 The 'Jüngling vom Magdalensberg', a lost bronze statue excavated near Klagenfurt in 1502, engraving in Lambeck's Commentariorum de Augustussima Bibliotheca Caesarea, II (1669).

Lambeck, who was in a position to work with Strada's original drawings, liked them so much that he did not really question their reliability as archaeological documentation, and though Patin was more cautious, he likewise took Strada's labours seriously. Though Strada's volumes would remain objects of interest to Grand Tourists, such as James Boswell, their attraction for professional scholars soon was to fade. ${ }^{16}$

\subsubsection{Works of Reference}

Lambeck's, Patin's and Cyprian's publications assured Strada a place in many antiquarian reference works appearing during the eighteenth century, such as Johann Albert Fabricius' Bibliographia antiquaria, a bibliography of modern studies into Hebrew, Greek, Roman and (Early) Christian antiquities that was first published in Hamburg in 1713, and in Fabricius' edition of Anselmo Banduri's Bibliotheca Nummaria of 1719, who also refers to the manuscript

in Vienna, the lost original is presumed to have been shipped to Spain in the sixteenth century where it was used in a fountain in the gardens of Aranjuez; cf. Gschwantler 1988 and Gschwantler 1993/94.

16 In his journal Boswell singled out Strada's volumes in the Gotha library, which he saw during his visit to the Gotha court in October of 1764 , 'dressed in a suit of flowered velvet of five colours'; Boswell / Pottle 1953, p. 146. 
volumes in Vienna, but already notes that these works, though in the past they had been highly esteemed, could now be little recommended for serious use. ${ }^{17}$ Strada's works also figure occasionally in dictionaries and bibliographies specializing in other fields, such as Johann Huebner's Bibliotheca genealogica (Hamburg 1729). Both Strada's edition of the Settimo Libro of Serlio's architectural treatise and the edition of his own technical drawings posthumously published by his grandson are included in the Kurzer Unterricht von den vornehmsten mathematischen Schriften, a bibliography of mathematical writings in the widest sense included as an appendix to Christian Wolff's Die Anfangsgründe aller mathematischen Wissenschaften. ${ }^{18}$ Strada's merit as a numismatic draughtsman, as shown in the prints in Lambeck's catalogue, also gained him entries in some of the earliest art-dictionaries, such as the Dictionnaire abrégé de peinture et d'architecture by François-Marie de Marsy, published in Paris in 1746, and in Rudolf Füssli's better known Allgemeines Künstler-Lexicon of $1763 .{ }^{19}$

As a consequence of these entries Strada was included in many of the general biographical dictionaries and historical encyclopaedias published in the eighteenth and nineteenth centuries. ${ }^{20}$ The entries are mostly succinct summaries of Strada's bibliography, based on notes taken from library catalogues and the earlier publications cited above. All that was known of Strada was based on the two publications of original material, i.e. the drawings engraved in Lambeck's catalogue of the Imperial Library and the preface to Strada's Series Imperatorum in Cyprian's catalogue of the holdings of the Ducal library at Gotha. Only in the nineteenth century the information offered in such entries

17 Fabricius 1713, p. 123; Fabricius 1716, pp. 536 and 540; Banduri 1719, pp. 10-11 (entry V-VI on Jacopo and his French translator Jean Louveau) and 53-54 (entry on Ottavio Strada).

18 Huebner 1729, p. 398; Wolff 1737, § 107 (p. 70); § 165 (p. 78 ).

19 Marsy 1746, II, p. 235; Füssli 1763, s.v. Strada, p. 531, and later editions: 'Strada, Jacobus <...> machte sich in dem XVI Jahrhundert durch seine Geschicklichkeit in Nachzeichnung anticker Medaillen berühmt $<\ldots$.. wie man solches auss einigen Mustern schliessen kan, welche Lambecius in seiner Beschreibung dieser vortrefflichen Bibliothek [i.e. the Imperial Library in Vienna] in Kupferstichen vorstellen lassen <... >. There is no mention of Vorsterman's print of the Strada portrait in the annexed list of engraved artists' portraits: like earlier writers Füssli appears to have been unaware of the identity of its sitter.

20 Moreri 1740, VIII, s.v. Strada, p.382 (Strada is not included in earlier editions); Zedler 1744 [1962] 40, s.v. Strada, col. 479-480; Jöcher 1750-51 [1960-1961], IV, s.v. Strada, col. 864; Biographie universelle 1811-1829, s.v. Strada; idem, nouvelle edition, s.a., T. 40, pp. 300-301; Nouvelle Biographie 1865, s.v. Strada, col. 540-541. The article in the Biographie universelle is signed by A-g-s, for Domenico de Angelis, who also signed the article in an Italian version, Biografia universale 1829, pp. 198-199. 
slowly shifted from the merely bibliographical to the summarily biographical. Their authors began to include details about Strada's life taken from an obvious source that had always been available, but had rarely or never been used: the prefaces and dedications of the books he had published. ${ }^{21}$ Thus the entry on Strada in the Biografia Universale of 1829 contains the characteristic phrase: 'He also gave the example of trading in works of art and of enriching strangers at the expense of Italy', which the slightly later Nouvelle biographie générale renders as 'It was on behalf of Germany that he despoiled Italy <... >'. Both passages closely echo Strada's own account of his acquisition of large quantities of antiquities in Venice, on behalf of Hans Jakob Fugger and Duke Albrecht $\mathrm{v}$ of Bavaria, 'which I myself, with great effort and at great expense, divesting Italy of its most noble spoils, had brought to Augsburg'. In the otherwise identical Italian version of the dictionary, Domenico de Angelis, the (Italian) author of this entry, takes Strada sternly to task for this unpatriotic behaviour: 'He also gave the example, fatal to his fatherland, of trading <'traficare'> in works of the fine arts, thus enriching the foreigners to the injury of his Italy'.22 Is this ominous word 'traficare' the first intimation of Pope-Hennessy's abject, commercial 'dealer in antiques'?

\subsection{Quellenkunde: Some Sources Published in the Nineteenth Century}

Only in the nineteenth century, when the growing interest in regional and national history and culture caused local authors and antiquaries to delve deeper into the holdings of their libraries and to explore the local archives, further new source material on Strada was unearthed and published. The first instance is provided by the prince of eighteenth-century Italian erudites, Girolamo Tiraboschi, whose Storia della letteratura Italiana of $177^{2-1778}$, a prime example of cultural history in the wider sense, foreshadows the Romantic interest in the contribution of the individual intellectual, artist or patron to literature

21 In particular his Epitome thesauri antiquitatum, Lyon 1553, which had been reprinted several times and could easily be found, and his editions of Caesar and of Serlio's Settimo Libro, both printed at Frankfurt in 1575 .

22 Biographie universelle s.a.: 'Il donna aussi l'example de trafiquer des objets d'art et d'enrichir les étrangers aux dépens de l'Italie'; Nouvelle Biographie generale 1855: 'Ce fût au profit d'Allemagne qu'il dépouilla l'Italie <...>”; Caesar 1575, p.*4: "quae ego magna vi pecuniarum expensa Augustam, nobilissimis spoliis exuta Italia, advexi"; Biografia universale 1829: "Ei diede pure l'esempio funesto al paese di lui di trafficare di oggetti di belle arti, arrichendo così gli stranieri con danno della sua Italia'. 
and the arts. He complemented a brief mention of Jacopo Strada with the transcription of a letter by Ottavio Strada to the Duke of Ferrara about his father's heritage, a letter Tiraboschi had found in the Archivio Estense. ${ }^{23}$ Naturally interest in Strada was strongest in his hometown, Mantua, where brief entries on his career were included in works studying the history of Mantua and revaluating its local cultural heroes. ${ }^{24}$ More valuable contributions were due to the two first serious students of the Gonzaga archives, Count Carlo d'Arco (1799-1872) and Stefano Davari (1835-1909). Carlo d'Arco's Delle famiglie mantovani, a compendium of historical and genealogical notes on Mantua, included a detailed genealogy of the Strada family. He moreover devoted a brief notice to Jacopo in his Delle arti e degli artefici di Mantova of $1857 \cdot{ }^{25}$ At about the same time, in his Lettere artistiche inedite, another aristocratic amateur of history and the arts, marchese Giuseppe Campori (1821-1887), published a letter from the Modena archives documenting Strada's connection with a cadet branch of the Gonzaga. ${ }^{26}$ Similar research in archival sources uncovered a completely new aspect of Strada's personality, his religious heterodoxy, presented in passing by the founding genius of the Mantuan State archives as a first-class historical research institution, Stefano Davari, in his chilling notes on the persecutions by the Inquisition in Mantua in the second half of the sixteenth century. Davari was also the first to publish and discuss Strada's description of the Palazzo del Te, a prime document for the history and the interpretation of that monument. ${ }^{27}$

In Austria, Strada's homeland by adoption, the increasing interest in such primary archival sources, which accompanied new approaches and methods in historiography, was reflected in Johann Evangelist Schlager's Materialien zur österreichischen Kunstgeschichte, the fifth volume (1850) in the Archiv für Kunde österreichischer Geschichtsquellen, published by the Imperial Academy of Sciences. This is a useful but rather unsystematic summing up of facts gleaned from archival and printed sources, covering a period from the mid-sixteenth up to the mid-eighteenth century. Unfortunately references are only sketchily indicated, and the wording is Schlager's own. Thus his influential statement

\footnotetext{
23 Tiraboschi 1772-1778, cited from Tiraboschi 1824, pp. 1245-1246.

24 Bettinelli 1774, p. 57 and p. 108; Coddè 1837, pp. 142-143.

25 Annotazioni genealogiche di famiglie mantovane che possono servire alla esatta compilazione della storia di queste, s.d., ASMn, Documenti patrii 220, vol. vii, fols. 65-75; it remained in manuscript, but is was accessible to later researchers in Mantua; D'Arco 1857 (b), pp. 283; Arco also referred to Strada in his biography of Giulio Romano: Arco 1842 , p. xci.

26 Campori 1866, p. 5o, letter nr. LXI; cf. Doc. 1568-06-16.

27 ÖNB-HS, Cod. 9039, fols. 154-155; printed in Davari 1889 and Verheyen 1967, pp. 68-69.
} 
that Strada in 1566 would have been appointed 'Aufseher', supervisor of curator, of the Imperial Kunstkammer cannot be corroborated in the sources known at present: it is probable that it is in fact Schlager's own interpretation of the title 'Antiquarius', which is used in the act he presumably cites. ${ }^{28}$ Standards of selection, transcription and interpretation of archival sources quickly improved, however. The most important results of this process soon found their way into a series of appendices to the Jahrbuch der Kunsthistorische Sammlungen des allerhöchsten Kaiserhauses, which began to be published in 1883, together with the Jahrbuch itself. These appendices presented a large quantity of impeccably edited sources relevant to the history of art in the Habsburg lands. The intelligent selection of materials was primarily intended to help establish the attributions, the provenance and the patronage situation of the works of art in the collections of the Austrian Emperors, i.e. basically what is now the Kunsthistorisches Museum in Vienna. But it is obvious that it was also intended to provide the documentary basis for a more general history of the visual arts of the Habsburg Empire, including architecture, the applied arts and archaeology, with particular emphasis on the laudable role of the Habsburgs as generous and discerning patrons. The documents published here first gave some substance to Strada's role as antiquary to the Holy Roman Emperor. Until then nothing more was known about this role except the title he added to his name on the front page of the books he published and had inserted in the cartouche he had painted on his portrait. These documents—often simple records of the payment of his salary and his travel expenses, sometimes more informative documents such as letters or reports - do at least tell us when and how Strada came to the Imperial court and when and why he resigned, and provide us with some inkling of the type of activities in which he was employed. ${ }^{29}$

In Vienna the interest in Strada was perhaps stimulated by the discovery of a volume of drawings by Ottavio Strada in the library of Count DietrichsteinMensdorff, which contained elaborate designs for goldsmith's work. These splendid drawings made a great impression: this was after all the period of the Great Exhibition, the foundation of the Victoria and Albert Museum and countless other museums and vocational schools for the applied arts. To stimulate

28 Schlager 1850, pp. 674-675, 682, 760-761; the record referred to is probably Doc 1566-08-10.

$29 J d K S 1883$ and following years; the documents printed in the appendices are grouped according to their location, which include non-Austrian institutions such as the Gonzaga archive in Mantua. They are mostly published as brief summaries (Regeste), but often also in extenso; each Regest is identified by a running number. The tradition is unbroken, witness the publication of the inventory of the Kunstkammer of Rudolf II (Bauer / Haupt 1976). It would be very useful if the material were reissued in a digital version with integral indexes. 
and inspire contemporary designers and craftsmen the Vienna Museum für Kunst und Industrie reproduced the eighty-two drawings in a beautiful facsimile edition which came out in $1869 .{ }^{30}$ Strada's affinity with the goldsmith's art, and in particular his close connections with the leading German goldsmith of his time, Wenzel Jamnitzer, were demonstrated by documents published in the Jahrbuch der Sammlungen, and discussed in David von Schönherr's article on Jamnitzer's work for Archduke Ferdinand II of Tirol. Additional information was printed in Hampe's publication of the decisions of the Nuremberg City Council, published in $1904 \cdot{ }^{31}$

The information from sources of the Imperial court was complemented by research done in the archives of the other principal patron for whom Strada had worked, Duke Albrecht v of Bavaria. Though in Munich no similar programme to publish source material existed, in the Bavarian archives much of the material relating to the collections and other cultural activities of the Wittelsbach princes had always been preserved in separate files. These so-called Libri antiquitatum were examined and summarized in Stockbauer's extensive study on the artistic patronage of Duke Albrecht v of 1874 . Though sometimes mistaken or lacking in precision, Stockbauer was the first to show Strada's role in the conception of the Antiquarium of the Munich Residenz and in the acquisition of ancient and contemporary works of art on behalf of Duke Albrecht v. Because so much of its information related to acquisitions in Italy, the book was also of interest to students of Italian art and history. Thus within a few years Crowe and Cavalcaselle came to use it for their ground-breaking monograph on Titian-including the information on the painting of Strada's portrait. Though later detailed studies corrected and enlarged upon various aspects of Stockbauer's study, for a long time it remained the only comprehensive discussion of patronage and collecting at the Munich court in the sixteenth century. It is therefore not surprising that even in the 196os it still proved to be Pope-Hennessy's source on Strada's activities and character. ${ }^{32}$ Nevertheless, even here Strada was presented as only one among a welter of figures - artists, craftsmen, learned advisors, merchants, courtiers and councillors, princely competitors - who assisted or obstructed the Duke in his cultural ambitions. And this holds for most of the later studies in which Strada figures: in general he occupies a similar marginal place, and his activities are

30 Strada, Ottavio [ I ] 1869; the original codex, entitled Libro di disegni per far Vasella da Argento now preserved in Brno, University Library, Ms. Mk 4 (I.214); cf. Bukovinská / Fučíková / Konečný 1984, p. 65 and note 22, which cites the earlier literature.

31 Schönherr 1888; Hampe 1904, 1, pp. 414, 417, 434, 473-474, 535; 2, pp. 18-19.

32 Stockbauer 1874; Crowe/ Calvalcaselle 1877-1878; Hartig 1917, pp. 44 fols. and Hartig 1933a and Hartig $1933 \mathrm{~b}$ use the material more critically, but were not cited by Pope-Hennessy. 
discussed only in as far as they are relevant for the main topic of the specific publication.

\section{o.6 Kulturgeschichte before World War II}

This is even true of the one article of which Strada himself-or rather his portrait-is the principal theme, 'Zur richtigen Datirung eines Portraits von Tizian' of 1901 by Heinrich Zimmermann, a historian and archivist who earlier had contributed to the source publications in the Jahrbuch der kunsthistorischen Sammlungen. In this thoughtful re-examination of Stockbauer's sources (the originals of which had been sent to Vienna for him to consult) in the light of other archival material that had meanwhile become available or he had found himself in the Vienna archives, Zimmermann carefully reconstructs Strada's travels to Venice on behalf of Duke Albrecht V of Bavaria, but only with the aim of assigning as precise as possible a date to the Vienna portrait. This was not because of any lack of interest in Strada as such: on the contrary, Zimmermann limited himself here to the problem in hand, because he intended to publish a full biography of Strada, whom he deemed to be of great interest 'for the history of the collections dating from the Renaissance period in Austria and Bavaria'. In a footnote he cautions that all biographical notices on Strada published by that time contain more or less glaring and often misleading mistakes. ${ }^{33}$ Zimmermann never seems to have published any more of the material he had collected for his planned monograph, which never appeared. His research was not taken up by other Austrian scholars: only in his Geschichte der Sammlungen, part of a Festschrift intended to celebrate the fiftieth anniversary of the Kunsthistorisches Museum, but published only at the end of the Second World War, did Alphons Lhotsky pay some attention to the role Strada had played at the Imperial court. His is a succinct and substantially correct, though incomplete summing up of available literature and published sources. $^{34}$

33 Zimmermann 1901; p. 835, n.1: Da ich seit Jahren an einer eingehenden Biographie dieses für die Geschichte der aus der Renaissancezeit stammenden Sammlungen in Oesterreich und Bayern sehr interessanten Mannes arbeite und sie in nicht allzu ferner Zeit, mit allen documentarischen Nachweisen versehen, zu veröffentlichen gedenke, kann ich mich hier auf die Anführung der für unsern Zweck nöthigsten Daten und die Bemerkung beschränken, dass alle bisher über ihn veröffentlichten biographischen Angaben an mehr oder weniger groben, zuweilen irreführenden Unrichtigkeiten kranken, die zu widerlegen, ich jener grösseren Arbeit vorbehalten muss $<\ldots .$. '.

34 Lhotsky 1945, pp. 160-163; it appears unlikely that Lhotsky used Zimmermann's unpublished material. 
The publication of material from the Bavarian and Austrian archives reflected a growing interest in detailed factual cultural history based on source material, and provided incentives and materials to its practitioners. For Munich the principal student was the librarian and intellectual historian Otto Hartig, whose Gründung der Münchener Hofbibliothek durch Albrecht v. und Johann Jakob Fugger, published in the middle of the First World War, is perhaps the best history of any library ever written. Here for the first time some attention was paid to Strada's role in the creation of the Munich Hofbibliothek and the contiguous Antiquarium, and some hints were given of his close and fruitful relationship with his first known patron, Hans Jakob Fugger, many of whose intellectual preoccupations seem to have been shared by his protegé. In his posthumously published survey of Hans Jakob Fugger's life and career, Wilhelm Maasen, a young historian and sad casualty of the First World War, evoked the intellectual circle where these ideas first came to fruition. ${ }^{35}$ In Hartig's later studies of the Kunsttätigkeit at the Bavarian court he not only published new archival data on Strada, but also illustrated and discussed Strada's architectural designs for the Munich Antiquarium. ${ }^{36}$

'Schwer fassbare, universelle Persönlichkeit von grosser Vielseitigkeit und Wandelbarkeit, die Wohnsitz, Wirkungsstätte und Tätigkeit häufig wechselte'. Thus Fritz Schulz characterizes Strada in the succinct but basically sound summary of the evidence available at the time in his entry on Strada in volume $3^{2}$ of Thieme-Beckers Allgemeines Künstler Lexikon, which came out in 1938. Though he probably errs in Strada's date of birth, and unnecessarily speculates about Strada's origin, his is perhaps the only attempt before the Second World War to present a balanced and complete view of Strada's career. ${ }^{37}$ It is no coincidence that it is found in an art-historical work of reference: though not really an artist, though not really an artistic patron, though intensively concerned in many cultural and intellectual pursuits other than the purely artistic, there can be no doubt that the visual arts remain Strada's central concern. It is therefore not surprising that modern discussions of Strada's activities can be found - with very few exceptions - in the pages of art-historical publications.

35 Hartig 1917(a), pp. 44-46; 50-53, 214-215; Maasen 1922.

36 Hartig 1931, pp. 342, 346, 348, 353; Hartig 1933 (a), Par. 9: 'die Erwerbung von Antiken' (pp. 211-219 ) und 10. 'Das Antiquarium und die Bibliothek' (pp. 220-225).

37 Schulz 1938. The supposed Netherlandish origin of the Strada family, based on the similarity of its name with that of the Flemish engraver Jan van der Straeten (Stradanus), is without any foundation (for Strada's origins, see below, Ch. 1.1). 


\section{o.7 Romance: Josef Svátek and the Rudolfine Legend}

Before we turn to contemporary scholarly interest in Jacopo Strada, however, it is necessary to turn back for a moment to magic Prague of the nineteenth century, and to Josef Svátek (1835-1897), a Czech autor who happily and rather unscrupulously combined the vocations of journalist, novelist and historian. He was absolutely fascinated by the history of the sixteenth and early seventeenth century, and published more than twenty historical novels, most of which were set in this period. This implies that he possessed a fertile imagination, which he drew upon perhaps even when he intended his writings to be factual history, rather than fiction. Certainly the long article on the Strada family at court in Vienna and Prague he contributed in 1883 to Sbornik historický, a new review published by a young professor at the Czech university of Prague, was presented as a careful investigation of source material. ${ }^{38}$ It is clear that Svátek not only used the source publications available at the time, but had himself consulted both the archives in Prague and Vienna and had studied much of the manuscript material from Strada's studio that had been preserved in the Imperial Library and collections. ${ }^{39}$

Unfortunately he did not provide exact references, so it is difficult to be certain of his contentions when no other indications are available - some of which are unlikely, and others demonstrably false. In particular the big claims he makes for the components of the tasks of Jacopo and of Ottavio Strada as Imperial antiquaries-he sees them as principal curators of the celebrated Kunstkammer of Rudolf II-are difficult to corroborate: in fact there are few indications that Jacopo played any role at court after Rudolf's accession, rather the contrary ${ }^{40}$ It is even more difficult to believe that Svátek did not

38 Svátek 1883; I am very grateful to Dagmar Stiebral to have read and summarized the article for me. Earlier Strada had been discussed in the chapter 'Die Rudolfinische Kunstkammer in Prag', in a volume of essays, Culturhistorische Bilder aus Böhmen (Prague 1879) (Svátek 1879, pp. 227-272).

39 He discusses not only the numismatic volumes dedicated to Ferdinand I and Maximilian II mentioned by Lambeck and later authors, but also some of Strada's other libri di disegni in Vienna that have never been published.

40 Svátek followed Schlager's interpretation of the term 'Antiquarius' (cited above): 'In 1565 treffen wir ihn [= Strada] zum erste Male am Wiener Hofe, wo er, wie die Hofacten beweisen, als Hofbaumeister, doch schon im nächsten Jahre als "Antiquarius" des Kaisers Maximilian II erscheint. Diese neu creirte Stelle eines Aufsehers über die kaiserliche Kunstkammer war mit dem jährlichen Solde von 100 fl. dotirt, eine Summe, die es erklärlich macht, dass Strada auch in dieser Stellung seinem früheren einträglichen Geschäfte oblag' (Svátek 1879, pp. 232). 
deliberately dramatize the story of Anna Maria Strada, an illegitimate daughter of Ottavio Strada who became Rudolf II's mistress and mother of two of his children. In Svátek's version of the facts she is renamed Katharina instead of Anna Maria, she is the daughter of Jacopo, instead of his granddaughter, becomes not only the mistress but even the morganatic wife of the Emperor, and the mother of (all of?) his illegitimate children, including the mad Don Julius.

This fictionalized account of the affair had a wide appeal, witness the history painting by Jan Skramlík (1860-1936) which had been illustrated in the Czech review Ruch of 1887 [Fig. 0.13]. ${ }^{41}$ Thus Strada became part of the web of legend about Rudolf II the melancholic recluse, living amongst his art treasures surrounded by artists, alchemists and astrologers. This legend has been retold and reconstructed from its literary sources in Angelo Maria Ripellino's magisterial essay Praga Magica of 1973, but its historical basis has been carefully examined and partially deconstructed in Robert Evans' Rudolf II and his

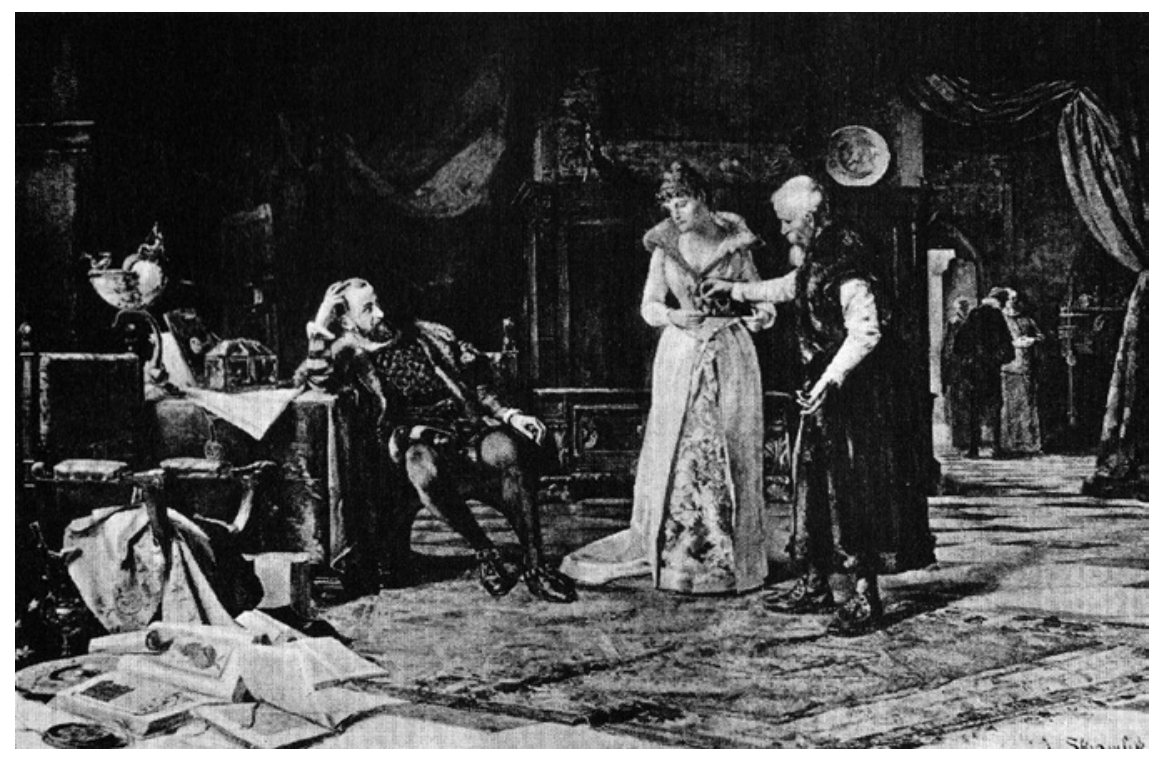

FIGURE 0.13 Jan Skramlík, Rudolf II visits the studio of his Antiquary Jacopo Strada, who introduces his daughter Katharina to the Emperor, after a painting reproduced in the Czech periodical Ruch, $\mathrm{x}, 1887$.

41 I am grateful to Eliška Fučíková to have drawn my attention to this image. A version (or copy?) of the original painting (oil on canvas, $55 \times 80 \mathrm{~cm}$ ) was recently sold at auction (Rempex auction house at Warsaw, May 21, 2003, lot 226); the print shows a different background. On Anna Maria Strada and her relation to Rudolf II, see Jansen 1988a, pp. 132-133, 143, notes 1 and 5, and now the exhaustive survey on Rudolf's children, Sapper 1999. 
World of the same year. ${ }^{42}$ Svátek himself was largely responsible for this legend, and he continued to draw upon it for his historical novels, in one of which at least, Astrolog of 1891-1892, the three Stradas-Jacopo, Ottavio and 'Donna Katharina'-play an important role. ${ }^{43}$

The Czech legend of Rudolf II crossed the Atlantic in 1904, when the American chemist and bibliographer Henry Carrington Bolton in his The Follies of Science at the Court of Rudolf II told the history of the alchemical experiments attempted at Rudolf's court from the point of view of the positivist scientist, as the title indicates. He merely mentions Jacopo Strada as the man responsible for the development of Rudolf's Kunstkammer, and 'Katharina' is not even mentioned by name, though she figures prominently in the frontispiece, a print of Václav Brožík's painting Rodolphe chez son alchimiste that had likewise crossed the Atlantic, and hung in the entrance of New York's Lenox Library [Fig. 0.14]. ${ }^{44}$

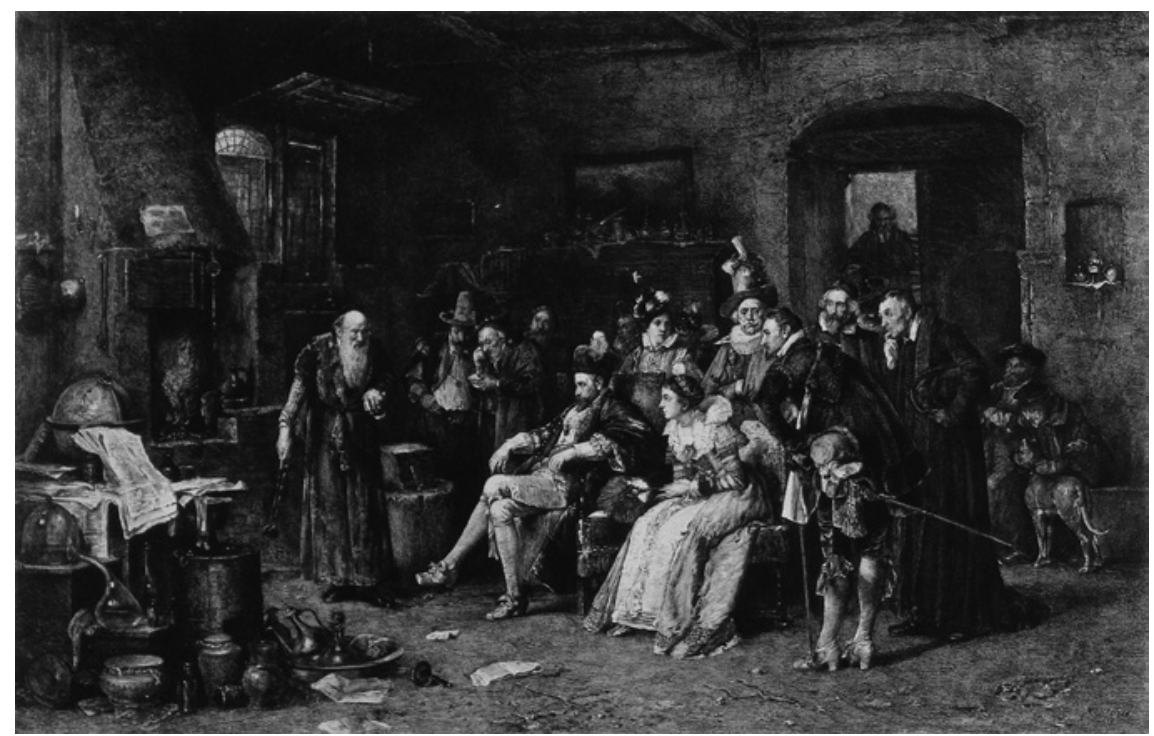

FIGURE 0.14 Václav Brožík, Rudolph with his Alchemist, engraving by Armand Mathey after a painting a reproduction of which served as the frontispiece to Henry Carrington Bolton, The Follies of Science at the Court of Rudolf II, 1904.

42 Ripellino 1973; Evans 1973.

43 Svátek 1891-1892, pp. 300 ff., pp. 474 ff., and passim. It is inevitable that these misconceptions continue to flourish. On the internet Katharina has taken on a new lease on life, and her 'father' has expanded his career by running a high-class brothel in Prague.

44 Bolton 1904 pp. 53-6o. 'In company with Strada, Rudolph spent entire days in the cabinets, devoting his nights to his astrologers and alchemists'. Bolton acknowledged his debt 
Some of Svátek's contentions would be repeated in Czech literature even when of a purely scholarly kind. Some authors added their own presumptions, such as Antonín Truhlár, a professor at the famous Prague academic gymnasium. In its library he had found a copy of the history of the Dutch Revolt by the famous Jesuit historian Famiano Strada, on which he published a short note 'On the Genealogy of the Strada von Rosberg' in which he asserts that Famiano (born in Rome in 1572) were a grandson of 'the elder Strada', that is, of Jacopo Strada. ${ }^{45}$ Some of Svátek's contentions also reappear, again without documentary corroboration, in Cyril Straka's reasonably detailed survey of the activities of both Jacopo and Ottavio Strada of 1916. This was valuable nonetheless, because Straka had taken the trouble to examine most of their printed and manuscript works, of which he includes a summary discussion. He pays particular attention to the album in his own care as librarian of the Strahov monastery at Prague. A similar survey by Eugen Jaroslav Schulz, stressing Jacopo and Ottavio's numismatic work, dates from 1950, but for its historical underpinning it still leans largely on Svátek and Straka. ${ }^{46}$ Since they were written in Czech, the information in these articles was in general ignored by later authors.

\section{o.8 A (Very) Modest Place in the History of Classical Scholarship}

Schulz was a numismatist and his article appeared in a Czech numismatic periodical. It is clear that Strada's work was interesting to the modern numismatist as a modest chapter in the history of his discipline, rather than for any light it might shed on actual questions. Unlike great minds such as Scaliger and Lipsius, Strada did not contribute substantially to the development of classical history, and he rarely figures in the history of classical scholarship: his standing can be measured by the two dismissive sentences he receives in Eric Cochrane's five hundred-page Historians and historiography in the Italian Renaissance, where he is merely mentioned as an Italian scholar employed

to Svátek's work (p. 56). The painting by Brožík illustrated served as frontispiece and was briefly described in the preface. I have not been able to establish its present location.

Truhlář 1883, p. 421; it was published in the same volume of Sborník Historický as Svátek's essay. Though the contention is repeated from time to time, it is without foundation. Other Czech authors from this period paid attention to Strada: Rybička/Zub 1884; Salaba 1902(1903).

46 Straka 1916; Schulz 1950. 
abroad, rather than as numismatist. ${ }^{47}$ Perhaps the only really scholarly appreciation of his antiquarian work in this field appeared already in 1869, in Emil Hübner's introductory note to the edition in the Corpus Inscriptionum Latinarum of a selection of Latin inscriptions from Spain which Strada had added, probably as an afterthought, to his edition of Caesar's Commentaries of 1575 . Though he has an open mind about Strada-'homo minime doctus, sed callidus rerum antiquarum indagator'-he clearly does not accept him as a serious scholar. Nevertheless he is the first to cite not only Strada's numismatic albums, but also the other manuscript materials preserved in the Österreichische Nationalbibliothek, including Strada's testament and the list of the books he intended to publish. Hübner apparently tried to identify the book containing over five thousand inscriptions Strada claimed to have collected, but finally had to be satisfied with guessing at the provenance of the Spanish inscriptions included in Strada's Caesar edition. ${ }^{48}$

\section{o.9 Contemporary Scholarship}

\subsubsection{History of Art and Cultural History}

Whereas Strada's numismatic publications do not excite the interest of modern archaeologists, they do attract scholarly attention of those interested in the reception of classical Antiquity in the Renaissance. An early example is the German art historian Paul Ortwin Rave, who places Strada's treatise within an old and continuing tradition for which he coined the term Bildnisvitenbücher, that is books in which the lives of illustrious heroes from the past were illustrated by a portrait, from which, it was held, their characters could be inferred. Since these images were often derived from true or spurious ancient coins (the Roman Emperors are obvious examples), a woodcut or engraved medallion became the accepted format for such portraits even of those heroes whose likeness had certainly never graced a coin or medal. ${ }^{49}$ Such 'portraits of the past' are the point of departure for Francis Haskell's wonderful book on the role of the image in our conception of the past, History and its images of 1991. In its very first chapter, 'The Early Numismatists', Strada's Epitome thesauri antiquitatum is discussed in detail, and in the following chapter it is linked to his part in

47 Cochrane 1981, pp. 350-351. Presumably because Cochrane limited his discussion to books published in Italy, Strada does not figure among the Italian numismatists listed in the chapter on the study of antiquities.

48 Hübner 1869, pp. ix-x.

49 Rave 1959, pp. 150-152. 
the creation of the Munich Antiquarium..$^{50}$ The Epitome is likewise discussed, in relation to the Titian portrait and Strada's career, in John Cunnally's Images of the Illustrious: The Numismatic Presence in the Renaissance of $1999 .{ }^{51}$

Francis Haskell and John Cunnally are both examples of art historians interested as much in the context of a work of art as in the object itself. It is obvious that Jacopo Strada appeals more to this type of cultural historian than to the connoisseur: after all very few of Strada's own works have been identified, and most of these are copied or derived from other works of art-and this holds notably for his most typical work, his numismatic drawings. These show him to have been a competent draughtsman. The very few original inventions that can be securely attributed to him, though demonstrating a similar competence and a thorough comprehension of the artistic language of his time, can hardly be reckoned great works of art. So it is not surprising that modern scholarship on Strada generally has originated as a by-product of specialized research into various topics of the history of art and architecture of the sixteenth century, in which he figures in a subordinate role. Only two or three authors have attempted an overall survey of his career, and even then he appears always in the context of research into a theme where his role happened to have been relatively important. In the following a selection of publications discussing or referring to Strada will be briefly reviewed. They will be grouped by theme rather than chronologically.

\subsubsection{Contemporary Scholarship: Drawings and Designs for Goldsmith Work}

One of the themes that have attracted most interest are the designs for goldsmith's work after Giulio Romano and other Italian masters that are found in several albums from the studio of Jacopo and Ottavio Strada. These were mostly based on the huge collection of drawings by Italian masters in Jacopo's possession. As mentioned above, they were known in Vienna and Prague through the 1869 facsimile edition of Ottavio Strada's drawings in the album in the Dietrichstein collection, and the presence of the manuscript, first mentioned by Cyril Straka, in the monastery of Strahov at Prague. The Strahov album contains both original drawings by Giulio Romano and copies in the hand of the Stradas and/or their copyists. It has been carefully studied by Beket Bukovinská, Elišká Fučíková and Lubomir Konečný. They published an exhaustive catalogue of these drawings in the Jahrbuch der Kunsthistorische Sammlungen of 1984, which is the fundamental publication on this subject. On the basis of her

5o Haskell 1993, pp. 14-16; 36-39.

$5^{1}$ Cunnally 1999, pp. 26-33, 208-209 and passim. 
study of these drawings Fučíková had earlier attributed a set of very elegant numismatic drawings in Budapest to Ottavio and Jacopo Strada. ${ }^{52}$ The codex Chlumczansky, another album from Strada's collection now in the National Museum in Prague containing miscellaneous and mostly earlier antiquarian material, has been the subject of an equally conscientious edition by Vladimír Juřen. ${ }^{53}$ Both editions provide invaluable information on the origins and character of Strada's collection.

Several albums of copies of similar designs prepared in the Strada workshop have been preserved elsewhere, a number of which have been subject of a thorough examination by one of the great specialists of sixteenth-century goldsmith's work, John Hayward. ${ }^{54}$ In his wake some more similar material was identified by Peter Fuhring in the collection of Prince Waldburg-Wolfegg. Less convincing is the attribution to Jacopo Strada of another set of splendid drawings in a private collection, though it is clear that there are as yet unexplained connections between this series and Strada's collection. ${ }^{55}$ Of the greatest importance is Silke Reiter's exhaustive catalogue of a number of volumes of drawings traditionally attributed to the Nuremberg goldsmith, draftsman and engraver Erasmus Hornick. She shows that these drawings cannot integrally be attributed to Hornick, and carefully analyses the relationship of these albums with the workshop of Jacopo and Ottavio Strada, thus providing a solid foundation for any eventual integral inventory and analysis of the products of this workshop. Valery Taylor has been working on Giulio Romano's goldsmith's designs, including the copies in the albums from the Strada workshop, interpreting them in the light of the culture of the princely table in the Renaissance. ${ }^{56}$

52 Prague, Library of Strahov Monastery, ms. DL III 3; published in Bukovinská / Fučíková/ Konečný 1984; it is digitally accessible through the website www.manuscriptorium.com; Fučíková 1982.

53 Prague, Library of National Museum, ms. XVII A 6; Juřen 1986. The ms. is digitally accessible through the website www. manuscriptorium.com.

54 Hayward 1968 a; Hayward 1968 b; Hayward 1970; Hayward 1972; Hayward 1976, pp. 24-26, 46-48, 136-137.

55 Fuhring 2003; Lawrence 2007, catalogue of an exhibition in the Serge Sorokko Gallery, San Francisco; it consists of images of the drawings which are not discussed individually, preceded by an essay on Jacopo Strada; though these drawings appear to have a connection with the Strada workshop, the attribution to Jacopo Strada personally cannot be maintained. Part of the set of drawings was sold at Sotheby's New York, January 2010, as by 'Jacopo Strada and workshop', cf. Old Master Drawings 2010, cat.nr. 40-49, pp. 50-73 and Jansen 2014, pp. 164-166.

$5^{6}$ Reiter 2012; Taylor 2014. 


\subsubsection{Contemporary Scholarship: Architecture}

Some other components of Strada's huge collection of drawings have likewise been the subject of detailed study. Principal among these are what the American scholar William Bell Dinsmoor in a ground breaking article in the Art Bulletin of 1942 termed 'the literary remains of Sebastiano Serlio'. Speculations as to the quantity and character of the material Strada obtained and his project to print the as yet unpublished books of Serlio's architectural treatise have since been exhaustively treated. This was first done in 1966 by Marco Rosci in his edition of the Munich manuscript of the Sesto Libro of Serlio's architectural treatise, then by Myra Nan Rosenfeld in her important article on Serlio's manuscript of the Settimo Libro in the Österreichische Nationalbibliothek in Vienna and in her edition of the Columbia University manuscript of the Sesto Libro. The Serlio conference at Vicenza in 1989 provided the present author with an opportunity to present and discuss the results of a detailed examination of the documents. Finally Francesco Paolo Fiore and Tancredi Carrunchio summed up the state of the question in the introduction to Architettura civile, their edition of the Vienna and Munich manuscripts of the Sixth, Seventh and Eighth Books of Serlio's treatise of $1994 .{ }^{57}$ These new findings were also discussed in Sebastiano Serlio: Architecture et Imprimerie, the publication edited by Sylvie Deswarte-Rosa presenting the results of an international research project centred around an exhibition and a conference on this theme in 1998. Sabine Frommel's important monograph on Serlio, concentrating on the work of the architect itself rather than on the publishing history of his writings, refers to Strada only when relevant and in passing. ${ }^{58}$

Of equal interest for the history of sixteenth-century architecture are the detailed drawings of the facades and the complete decoration of the Palazzo del Te in Mantua that Strada commissioned in 1567. These were known to have existed from the sources, and they were already referred to in Hartig's history of the foundation of the Munich library survey by Duke Albrecht v, for whom this documentation was made, and in Elizabeth Herget's article on the influence of the Palazzo del Te on the architecture north of the Alps during the later sixteenth century. ${ }^{59}$ The drawings themselves, which were preserved in the Kunstmuseum in Düsseldorf with an old attribution to Santi Bartoli, were only identified later in the 1960s by Egon Verheyen, who dedicated a long article to them. On the basis of their obvious connection with Strada's manuscript

57 Dinsmoor 1942; Rosci/Brizio 1966, Rosenfeld 1974; Rosenfeld 1978; Jansen 1989; Fiore/ Carrunchio 1994.

$5^{8}$ Sebastiano Serlio A Lyon, 2004; Frommel 1998.

59 Hartig 1917, pp. 52-53; Herget 1963, pp. 288-289. 
description of the Palazzo del Te published by Davari in 1889, of available data culled from the Munich sources, and of a comparison with Strada's numismatic drawings and his designs for the Munich Antiquarium, Verheyen attributed the drawings to Strada himself. He also pointed out their crucial importance for a good understanding of the genesis and iconography of the Palazzo del Te and its decoration. Soon a discussion developed between him and the American architectural historians Kurt Forster and Richard Tuttle about a possible ideological intent of the building, and about the reliability of Strada's drawings. ${ }^{60}$

These drawings were not, however, in Strada's own hand: he had merely commissioned them from the young Mantuan painter Ippolito Andreasi, as Renate von Busch demonstrated on the basis of an even more attentive reading of the available documents. In 1984 Richard Harprath catalogued them in his long article in Master Drawings on Ippolito Adreasi as a draughtsman. ${ }^{61}$ Some years later a selection of the drawings was shown in the large exhibition on Giulio Romano within the walls of the palace they documented, and they were used in the preparation of its restoration. ${ }^{62}$ They were moreover illustrated in Amedeo Belluzzi splendid 'atlas' of the Palazzo del Te, two beautiful though unaffordable volumes illustrating the architecture and every single decorative element of this important complex. Belluzzi provided a transcription of Strada's accompanying description and discussed both his acquisition of Giulio's drawings and his commission of Andreasi's designs. ${ }^{63}$ Meanwhile, in an article about later pictorial additions to Raphael's Vatican Loggia, Bernice Davidson discussed the even more detailed and splendidly illuminated documentary drawings of this other key monument of the history of the Renaissance, which had been commissioned by Strada a decade before those of the Palazzo del Te. ${ }^{64}$

In 1617 Jacopo Strada's grandson Ottavio II published a volume of technical designs under his grandfather's name. This book was first seriously discussed in an article on 'plagiarists' of Francesco di Giorgio Martini's technical designs, published by Ladislao Reti in 1963. Until the discovery, by the French antiquarian booksellers Bernard and Stéphane Clavreuil, of a manuscript containing autograph drawings by Jacopo of similar technical inventions, these had only been known through some similar manuscripts prepared by Jacopo's son, Ottavio I Strada, which were presented to various European princes. One of

\footnotetext{
$60 \quad$ Verheyen 1967; Forster / Tuttle 1971; Verheyen 1972(b).

$61 \quad$ Von Busch 1973, pp. 204-205 and p. 342.n. 90; Harprath 1984.

62 Giulio Romano 1989, pp. 333-334; 339; 342; 350, 357, 366; 400-402; 409-415.

63 Belluzzi 1998, pp. $30-36$ and passim.

64 Davidson 1983, pp. 587-599 and passim.
} 
these manuscripts was dedicated to Don Giovanni de' Medici and is preserved in the Museo delle Scienze in Florence. A publication of this volume sponsored by ENI, the National Electricity Network of Italy, presented the opportunity to place these drawings in context. Thomas DaCosta Kaufmann treated the intellectual, technical and military concerns of the sixteenth century, the present author wrote about the workshop and later history of three generations of Strada's, and Luisa Dolza and Vittorio Marchis discussed the development of this specific type of literature in the sixteenth through eighteenth centuries. Unfortunately it proved not possible to include a detailed analysis of each technical invention and its probable sources. ${ }^{65}$

In his 'Kunsttätigkeit in München unter Wilhelm IV und Albrecht v' of 1933 Otto Hartig presented Strada's designs for the Munich Antiquarium, and was thus the first to demonstrate that Strada was himself actively involved in the architectural projects of his patrons. ${ }^{66}$ This information allowed Renate Rieger just after the Second World War to attribute to Strada some part in the conception of the Neugebäude, the extensive pleasure garden just outside Vienna laid out for the Emperor Maximilian II. She observed correspondences in form and construction between its principal element, a huge half-open gallery built over two immense, vaulted halls, and the Antiquarium, which led her both to postulate a similar function for the Neugebäude, and to attribute a role in its conception and design to Jacopo Strada. ${ }^{67}$ In his short monograph on the Neugebäude of 1976 Rupert Feuchtmüller follows this up with some more arguments, without assigning any concrete role to Strada. ${ }^{68}$

Certainly the Antiquarium and the Neugebäude are of signal importance for an understanding of Jacopo's role at the courts of Munich and Vienna: the two best surveys of his career to date were published as a spin-off of research into their history. ${ }^{69}$ But even before that, Erich Hubala had discovered another, alternative design for the Antiquarium, and in his article of 1958 he carefully reviewed all the drawings and the most relevant documents. For the reception of this important article it was perhaps unfortunate that Henry RussellHitchcock, in his general overview of German Renaissance architecture of 1981, mixed up the drawings, publishing an image of the German alternative design under Strada's name instead of Strada's own drawings. This alternative design is in any case a source of misattributions; a later attribution to the Flemish

65 RETI 1963, pp. 297-298; Clavreuil 2001, cat. nr. 37; Marchis / Dolza 2002.

66 Hartig 1933(a), pp. 220-225 and Figs. 26-28.

67 Rieger 1951.

68 Feuchtmüller 1976, pp. 64, 80-81.

69 Von Busch 1973; Lietzmann 1987; cf. below. 
neo-Latin poet Niccolò Stopio by Heike Frosien-Leinz is based on a misreading of the sources. ${ }^{70}$

At about the same time that Hubala was going through the Munich archives in connection with the Antiquarium, in Vienna Harry Kühnel was collecting archival data to document the development of the Hofburg, the principal residence of the Habsburg Emperors in their capital during the sixteenth and seventeenth centuries. He published his findings between 1956 and 1961 in a series of articles in the Anzeiger der Österreichischen Akademie der Wissenschaften. ${ }^{71}$ In the third part, 'Die landesfürstlichen Baumeister der Wiener Hofburg von 1494 bis 1569', published in 1959, he included a brief but significant survey of Strada's career in Vienna. Though he cites only one document indicating that Strada had some unspecified share in the restructuring of the Hofburg complex under Ferdinand I and Maximilian II, Kühnel recognized that his presence in Vienna was of considerable interest for its history. ${ }^{72} \mathrm{He}$ carefully lists the references he found in the various archives, including many financial records which had not been published before. Kühnel is also the first who recognized the importance of Strada's will, of which he gives a summary.

\subsubsection{Renate von Busch and Hilda Lietzmann}

Jacopo Strada had a considerable share in the conception and realization of both the Munich Antiquarium and the Vienna Neugebäude. Research into the history of these two splendid monuments of the Northern Renaissance led to the two really extensive studies on Strada's career. The first of these is added as an excursus to Renate von Busch's 1973 Tübingen dissertation Studien zu deutschen Antikensammlungen des 16. Jahrhunderts. It is sad that this wonderful book, whose gifted author unfortunately died shortly after its completion, has never been republished in an illustrated edition. ${ }^{73}$ On the basis of exhaustive archival research, it provides a survey of the earliest collections of antiquities in Germany, culminating in a detailed chronicle of the genesis of Duke

70 Russell-Hitchcock 1981, pp. 92,95, 168 and 221, pl. 209; Frosien-Leinz 1983, pp. 359-361; cf. below, Ch. 8.4.

71 Kühnel 1956, 1958, 1959 and 1961; Kühnel summarized and amplified these notes in a short monograph on the Hofburg in which Strada does not figure, doubtless because no specific contribution is documented (Kühnel 1971).

72 Kühnel 1959, p. 319: 'Von nicht geringem Interesse im Zusammenhang mit der Baugeschichte der Wiener Hofburg darf die Tatsache bezeichnet werden, dass eine der vielseitigsten, universellsten Persönlichkeiten der zweiten Hälfte des 16. Jahrhunderts hier eine, wenn auch wenig fassbare Tätigkeit entfaltetet: Jacopo Strada'.

73 Von Busch 1973. Though published as a photographically reproduced typescript without illustrations, the book's significance was widely recognized: copies can be found everywhere and it has been cited very often. 
Albrecht v's collection and of the Antiquarium built to house it. Accurate critical reading of the many sources she consulted-including the Libri antiquitatum of the Bavarian State Archive mentioned above-led to the discovery of Strada's central role. His importance in this respect incited Von Busch to add the excursus in which she gave an ample and detailed survey of Strada's career. She is the first since Titian who, by judicious selection and ample citation of her sources, manages to evoke Jacopo Strada as an actual human being, with all his enthusiasms, his little vanities, and his obstinacy. She is also the first who implicitly seems to detect some coherence in Strada's very diverse occupations. Of particular moment are her appreciation of Strada's long-lasting and intimate relationship with Hans Jakob Fugger, and her noting, in their correspondence, of the passage which documents that Strada made designs for the Vienna Neugebäude as well as for the Munich Antiquarium.

Von Busch confirmed Renate Rieger's intimation that Strada was in some way implicated in the design of the Neugebäude merely in a footnote. It was investigated in detail in Hilda Lietzmann's monograph on that huge monument, a book which has put it on the art historical map and has doubtless stimulated the attempts of the last decades to rehabilitate its remains. ${ }^{74}$ Lietzmann provides the first more or less all-round appreciation of Jacopo Strada as an artist and places him in the context of the artistic and architectural patronage at court. She is the first to insist that Strada's salary as a court architect presupposes his serious involvement in at least some of the projects initiated by Ferdinand I and Maximilian II. She is the first to advance the plausible attribution of the design of the Stallburg to Strada. This annexe to the Hofburg was built for Maximilian II as heir to the throne between 1559, when Strada had just arrived, and $1565 .{ }^{75}$ With the Neugebäude she thus also puts Strada himself on the map, which resulted in sections both on the Neugebäude and on Strada himself in the Vienna version of the Giulio Romano exhibition of $1989-1990 .{ }^{76}$ As a follow-up, Lietzmann published some additional documents on Strada, highlighting certain unknown aspects of his later career. ${ }^{77}$ In a very interesting article published in 2006 Wolfgang Lippmann analyses the Neugebäude in the light of the results of material research on the complex, and places it in a wider European context, but adds little to Lietzmann as far as Strada's role in its

\footnotetext{
74 Von Busch 1987; cf. my review, Jansen 1988(b).

75 Lietzmann 1987, pp. 113-114.

76 Fürstenhöfe der Renaissance 1990, pp. 356-377 (on the Neugebäude); pp. 308-323 (on Strada, curated by the present author). Lietzmann 1997; Lietzmann 1998.
} 
conception is concerned. ${ }^{78}$ In contrast, the authors of the recent monumental and very useful, though excessively positivist study on the building history of the Vienna Hofburg totally ignore him. Not finding archival data immediately linking Strada to concrete interventions and not understanding Strada's position at court, their omission demonstrates a serious misapprehension of Strada's role, of his immediate influence on the development of parts of the Hofburg complex, and on the architecture in the Habsburg lands in general. ${ }^{79}$

\subsubsection{Modern Scholarship: Collecting and Princely Patronage}

Whereas Strada's contributions to the Antiquarium and the Neugebäude have been extensively researched, his other activities for his patrons in Munich and Bavaria have received less attention. Hartig's article on patronage and collecting at the court of Albrecht $\mathrm{v}$ has already been mentioned above; it was recapitulated, together with the results of Renate von Busch's research, in the general introduction of Herbert Brunner's Kunstschätze der Münchner Residenz of 1977. The antiquarian component of Albrecht's collections and Strada's contributions to it have since been discussed more fully in the huge two-volume catalogue of the sculptures in the Antiquarium edited by Ellen Weski and Heike Frosien-Leinz published in 1987 and its introductory essays. In particular Horst Stierhof's discussion of the building history of the Antiquarium and Frosien-Leinz's discussion of its significance in the sixteenth century are relevant for Strada's role. The book is moreover invaluable for the archival sources published in its appendix and its profuse illustration. ${ }^{80}$

Strada's influence on Albrecht's collection in general is mentioned in Lorenz Seelig's paper on the Munich Kunstkammer at the 1983 Oxford Symposium The Cabinet of Curiosities and discussed more fully by Mark Meadow in his initial exploration of Hans Jakob Fugger's importance for the development of the Munich complex of collections and its theoretical basis. The 1583 inventory of the Kunstkammer has recently been published in extenso, and was followed shortly afterwards by two huge volumes of catalogue and commentary, together providing as detailed a reconstruction of the Munich collections as will ever be possible. This adds immensely to our knowledge and understanding of this basically scholarly and scientific, rather than purely artistic institution. In the commentary volumes the material with which Jacopo had provided the

78 Lippmann 2006-2007. Lippmann unfortunately follows Lietzmann in a misreading of the passage in Fugger's letter, and adds another misreading to it; cf. below, Ch. 8.

79 Karner 2014. See below, Chs. 5.6, 10.7 and 16.1.

8o Weski/Frosien-Leinz 1987, includes pp. 18-22: Horst H. Stierhof, 'Zur Baugeschichte des Antiquariums'; pp. 32-64: Heike Frosien-Leinz, 'Zur Bedeutung des Antiquariums im 16. Jahrhundert' and pp. 452-479: 'Quellenanhang'. 
Kunstkammer are carefully described and put in context. ${ }^{81}$ Finally, the origin of the Munich Staatsbibliothek was described by its former director, Franz Georg Kaltwasser, in his overview of its history focusing on the display of its holdings, and more in general on its scholarly, scientific and cultural function. He does not, however, define Strada's role in this any more precisely than Hartig had done. In 2008, finally, the 450th anniversary of the founding of the Staatsbibliothek was celebrated with an exhibition and an accompanying catalogue in which a number of the materials provided by Strada are discussed and illustrated, often for the first time. ${ }^{82}$ Two years later Christien Melzer showed that materials from Strada's workshop were also included in the Dresden Kunstkammer, and briefly discussed and illustrated a number of libri di disegni still preserved in the Dresden Kupferstich-Kabinett. ${ }^{83}$

Interest in collecting has always been a Viennese speciality, witness not only the exemplary source publications in the Jahrbuch der Kunsthistorischen Sammlungen, but also Julius von Schlosser's influential, more theoretical essay, Die Kunst- und Wunderkammern der Spätenaissance of 1908. The origins of the imperial collections in Vienna were studied by Alphons Lhotsky on the occasion of the 5oth anniversary of the opening of the Kunsthistorisches $\mathrm{Mu}-$ seum. Rotraud Bauer and Thomas DaCosta Kaufmann were the first to suggest that the Kunstkammer of Emperor Rudolf II was influenced by the ideas of Samuel Quiccheberg which were transmitted by Strada. Elizabeth Scheicher pays some attention to Strada in her survey of Habsburg collecting of 1979, Die Kunst- und Wunderkammer der Habsburger, but in view of the inadequate concrete evidence available wisely refuses to speculate about his precise role. A letter by Strada to the Czech magnate Vilém z Rožmberka published by Fritz Eheim in 1963 provided evidence that Strada also worked for others than members of the dynasty. ${ }^{84}$

Most literature on patronage and collecting of the sixteenth-century Austrian Habsburgs focuses on Archduke Ferdinand II of Tirol and Emperor Rudolf

$81 \quad$ Seelig 1983; Meadow 2002; Diemer 2004; Diemer/Diemer/Sauerländer 2008.

82 Kaltwasser 1999, pp. 10, pp. 15-16 and passim; Kulturkosmos der Renaissance 2008, pp. 24-25; 28; cat. nrs. 93-95; and passim. Many codices from the Staatsbibliothek, including some of the Strada material, have now been made accessible on-line in full or in part on the website of the library: http://codicon.digitale-sammlungen.de.

83 Melzer 2010. My attention was drawn to these materials by Gudula Metze and Thomas DaCosta Kaufmann when I had already finsihed the first draught of this book. I have not yet been able to study them in detail, but they are briefly discussed in Chs. 13.7.1

84 Schlosser 1908 pays no particular attention to Strada; Lhotsky 1945, pp. 160-163; Bauer / Haupt 1976, p. xxxvii; Kaufmann 1978(b), p. 25 and p. 28, n. 16; Scheicher 1979, pp. 139-140. Eheim 1963 . 
II. It was only in 1995 that Karl Rudolf published a detailed study of such Kunstbestrebungen at the Imperial court before Rudolf II's accession, presenting many unknown sources and making an illuminating comparison with similar activities at the court of Maximilian II's cousin and brother-in-law, King Philip II of Spain. Strada is discussed in particular in his role as a numismatic expert. ${ }^{85}$ Rudolf does not explicitly question Schlager's characterization of Strada as an 'Aufseher auf die Kunstkammer', but he might well have done so, since he concludes, probably correctly, that at the time a more or less formal, centrally organized Kunstkammer as could be found at Munich, Ambras and later at Prague, as yet had not come into existence in Vienna. ${ }^{86}$

In his Rudolf II and his world of 1973, Robert Evans mentions several of Strada's activities in connection with the general intellectual milieu of the Imperial court during the second half of the sixteenth century. Of course Strada often briefly figures in monographs on other figures at that court, such as Augerius Busbequius and Joannes Sambucus. ${ }^{87}$ But he is rarely given more than passing attention in studies of the intellectual milieu of the period. Whereas Nicolette Mout, in her dissertation on the relations between Bohemia and the Netherlands in the sixteenth century, briefly sketches Jacopo and Ottavio's career, and is the first to mention Strada's attempt to have Christophe Plantin print his books, Strada is hardly mentioned in Paula Fichtner's predominantly political biographies of Ferdinand I and Maximilian II. ${ }^{88} \mathrm{~A}$ collection of essays on Maximilian II and his period edited by Friedrich Edelmayer and Alfred Kohler included an essay by the present author which attempted to clarify his formal position at the Imperial court. ${ }^{89}$ One aspect of his tasks at court was discussed in Thomas DaCosta Kaufmann's 1978 dissertation, Variations on the Imperial Theme in the Age of Maximilian II and Rudolf II, in which he was the first to discuss Strada's costume designs for various court festivities, and placed them in the larger intellectual and iconographical context at court. ${ }^{90}$ That Strada had

$85 \quad$ Rudolf 1995 , pp. 172-173, covering independently material published by the present author (Jansen 1993(a); pp. 195-196, p. 198).

86 Ibidem, p. 225; Rudolf doubts that Strada made designs for the Neugebäude (p. 177), and does pay no further attention to Strada's role as an architect; cf. below, Ch. 9.4.

87 Evans 1973,pp. 128-129; 185, 187; Martels 1989, passim.

88 Mout 1975, pp. 64-65, 166; cf. also Mout 2000, pp. 55-57; Fichtner 1982; Fichtner 2001, pp. 81,97 .

89 Jansen 1992, a revised version of an Italian paper read at a conference on royal and aristocratic households in the Renaissance (Jansen 1989(c)); it was drawn upon for Chapter 4 of the present book.

9o Kaufmann 1978(a), pp. 61-64 and passim; modified in Kaufmann 2009, pp. 78-80 and Kaufmann 2010. Some of the drawings were engraved by Jost Amman, whose prints and 
in fact a larger responsibility in this field than has previously been assumed follows from new finds in archives in Mantua and Vienna, published by Elena Venturini and by Otto Schindler, by the recent find and convincing attribution of two autograph designs for such festival costumes by Zoltán Kárpáti, and by the even more recent identification of two volumes of festival designs from Strada's workshop in the Dresden Kupferstichkabinett by Gudula Metze and Thomas DaCosta Kaufmann. Kaufmann has repeatedly returned to Strada also in other contexts. ${ }^{91}$

Following in Kaufmann's footsteps the intellectual historian Howard Louthan included a detailed investigation of Strada's career at the Imperial court in his The Quest for Compromise: Peacemakers in Counter-Reformation Vienna of 1997. In this book he selects four key-figures-'Peacemakers in CounterReformation Vienna'-whose exploits in various fields exemplify the conciliating or irenic aspirations of Maximilian and his entourage. The fields he discusses are politics, exemplified by Maximilian's general Lazarus von Schwendi; religion, illustrated by his personal physician Johannes Crato; humanist learning, illustrated by his librarian Hugo Blotius; and finally the arts, illustrated by Jacopo Strada, who, Louthan stresses, 'helped transform a more provincial Habsburg court into a sophisticated and international center of artistic activity'. In her article 'The appropriation of Italian Renaissance art by German courts', Barbara Marx accorded Strada an important place in this process, stressing his role as mediator in particular in the acquisition of antiquities by German princes. She considers such antiquities as explicit markers of the values (and the fashions?) of the Italian Renaissance as adopted by the more ambitious courts north of the Alps. They functioned as such both in the originals, such as those brought together in Duke Albrecht v's Antiquarium in Munich, and in their graphic representations, such as those provided by the Strada workshop: Marx is the first to publish illustrations from a manuscript of drawings of imperial busts Ottavio Strada presented to Grand Duke Francesco I of Tuscany. ${ }^{92}$

their documented connection to Ottavio Strada are discussed by Ilse O'Dell, who however did not recognize the link between these prints and the Strada drawings (O'dell 1990).

91 Venturini 2002, p. 102; Schindler 2004, p. 312; Schindler 2006, (p. 336).; Kárpáti 2012; Kaufmann, 'Giuseppe Arcimboldo: Learning, Letters, Art', in: Arcimboldo 1526-1593 2007, pp. 273-279. On the festival designs, including the as yet unpublished Dresden drawings, see below, Ch. 4.3.4.

92 Louthan 1997, p. 8. On Strada, see chiefly Ch. 2: 'Jacopo Strada and the transformation of the imperial court' (pp. 24-46); Marx 2007, pp. 204-214 and figs. 52-53. 


\section{o.10 What Has Not Been Written on Jacopo Strada}

The foregoing overview shows that almost everything ever written on Jacopo Strada was a spin-off of its author's specialized interest in one of the fields in which Strada had been active, rather than an intrinsic interest in the career of this rather unusual personality. Even the careful reviews of his career by Renate von Busch and Hilda Lietzmann were the result of their exhaustive investigations of the history of the collecting of antiquities at the Bavarian court, and of the history of Maximilian II's Neugebäude respectively. Given that most literature on Strada originates in such specialized research, it is not surprising that there remain some aspects of his career which have received little or no attention, even where such attention might have been expected.

It is, for instance, remarkable that the presence of his portrait has not excited greater interest in Vienna itself, where Strada reached the high point of his career. In the wake of Renate Rieger's suggestions only a few remarks have been made about his influence on the developments of local architecture, foremost by Hilda Lietzmann. An exception is Alfred Strnad's wide-ranging survey of the reception of the Italian Renaissance in the Habsburg Erblande based on a very thorough examination of the available secondary sources. He pays much attention to the artistic developments in the sixteenth century and, following Lietzmann, briefly discusses Strada's role..$^{93}$ Until recently the Vienna court of this period in general has been little studied, compared to the courts of Maximilian I, Charles V and Rudolf II. For the period of Ferdinand I, covering the first decade of Strada's career at court, this was remedied by the huge exhibition of the Kunsthistorisches Museum on the occasion of the fifth centenary of his birth in 2003. Though Strada was explicitly appointed as an architect by Ferdinand I, he does not figure at all in the catalogue, not even where existing documents might have made a discussion of his possible role useful, such as the Maximiliansgrab in Innsbruck. ${ }^{94}$

It is true that, at first sight, Vienna in the second half of the sixteenth century looks rather bleak, in contrast with the rich Middle Ages, culminating in the romantic figure of the 'Last knight', the Emperor Maximilian I, or with the baroque splendour of the Austrian court in the later seventeenth and the eighteenth centuries. But this bleakness-and the resulting lack of interest among scholars - can be partly explained by the dearth of (published) sources and the relatively few monuments from the period that have survived intact. Most research has been done by art historians who were often employed at the

93 Strnad 1991, pp. 180-181, 222-224.

94 Kaiser Ferdinand I 2003; Altfahrt 2003. 
Kunsthistorisches Museum and whose approach is necessarily more objectoriented than that of cultural or intellectual historians. However, Karl Rudolf's study on the artistic patronage of Maximilian II cited above has shown that the dearth of available sources might be remedied by more extensive and systematic archival research. ${ }^{95}$ This material doubtless contributed to the revaluation of the court of Maximilian II that is evident in the catalogue of the 2007-2008 exhibitions in Paris and Vienna dedicated to his court-painter Giuseppe Arcimboldo. There at least some attention was paid also to Strada's role at court. ${ }^{96}$

It is particularly odd that the materials from Strada's studio preserved in the Österreichische Nationalbibliothek and in the University Library of Vienna have hardly attracted any scholarly attention since Zimmermann. ${ }^{97}$ Even two contemporary lists of manuscripts and books from Strada's library that are probably of considerable value for the history of the early holdings of the Hofbibliothek - the list of printed books is an offer of sale, and the items listed were probably sold to Rudolf II by Strada or his heirs-has incited no interest; this in contrast with similar lists relating to acquisitions by or from contemporaries such as Joannes Sambucus and Hugo Blotius. ${ }^{98}$ In general very little attention has been paid to Strada's place in the history of the book, considering his close connection with two of the greatest libraries of the sixteenth century and his activities in the book trade in general. Doubtless this is largely due

95 Rudolf 1995; it should be noted that only the minutest part of Maximilian's correspondence has been published.

96 Karl Schütz, 'Art and Culture at the Court of Emperor Maximilian II', pp. 73-79 in Arcimboldo $1526-1593$ 2007, pp. 76-77.

97 The material is referred to by Renate von Busch, Thomas DaCosta Kaufmann, Hilda Lietzmann and Howard Louthan. It should be noted that the most illustrious of Viennese art historians, the late Ernst Gombrich, did study the Strada material in Vienna in the course of the preparation of his dissertation on Giulio Romano, and still remembered these in great detail fifty years later (oral communication, 1982) but he never published these findings. His dissertation was published only in 1984 in Italian, filling the first issue of the periodical Quaderni di Palazzo Te (Gombrich 1984b), but makes no mention of Strada.

98 Vienna, ÖNB-HS cod. 10101: a copy of the Index sive catalogus (a list of manuscripts Strada planned to publish) is followed by a list of 153 volumes of manuscripts, many containing several independent works; ÖNB-HS, cod. 9038, fols. $99 \mathrm{ff}$. is headed 'Index venalis: Catalogus ex bibliotheca Stradae', and lists a huge number of printed books, indicating format, short title, place of publication and price or estimate. To my knowledge these lists have never been compared to the present holdings of the Nationalbibliothek: unless later rebound, the manuscript volumes ought to be readily identifiable, and a comparison of bindings, ex-libris and/or shelf marks and annotations might possibly indicate a common provenance for some of the printed titles, which would confirm that Strada had also purveyed printed books to the Emperor. 
to the fact that he was not a locally established publisher, but had his books printed in three different countries.

Another strange lacuna in scholarship is Strada's role in the creative process of Wenzel Jamnitzer's workshop. In view of the available documents, printed already in the nineteenth and early twentieth century, it is inconceivable and unjustifiable that his name does not appear even once in the recent detailed, three volume survey of the history of Nuremberg goldsmith's work, an omission the less explicable since recent scholarship has at least indicated some intimations of his possible importance in this field. ${ }^{99}$

Other themes may not have been taken up because their intrinsic interest seems not to recompense the quantity of work-and expense-involved: the best example is Strada's Magnum ac novum Opus, the corpus of over nine thousand numismatic drawings preserved at Gotha. In spite of the fame it enjoyed in the seventeenth and eighteenth centuries, it has only recently been the subject of a preliminary material investigation. ${ }^{100}$ The modest quality of most of the drawings as works of art would not soon invite art-historical interest, and their value for modern numismatic studies is limited. They could, however, be of interest as documents of the intellectual preoccupations and scholarly procedure of the sixteenth century: for that reason the Deutsche Forschungsgemeinschaft DFG has decided to fund a project to digitize both Strada's coin-images in Gotha - which are already accessible on-line — and his related coin-descriptions. ${ }^{101}$

\section{o.11 Weaving the Strands Together: The Purpose of this Study}

It is clear that most available information on Strada comes from specialized publications, which illustrate only one or at most a few aspects of his career.

99 Only Ralf Schürer has explicitly wondered what Strada's role may have been: Schürer 1986 p. 58 ; cf. below, Ch. 2.5 .

100 Fürstliche Bücherlust 2004, pp.42-45; Kulturkosmos der Renaissance 2008, cat.nr. 94, pp. 262-263; Diemer/Diemer/Sauerländer 2008, nr. 5-34.

101 Jacopo Strada's Magnum ac Novum Opus: A Sixteenth-Century Numismatic Corpus, DFGfunded project at the Gotha Research Centre of the University of Erfurt, in collaboration with the Forschungsbibliothek Gotha and the Census of Antique Works of Art and Architecture known in the Renaissance, Berlin; conducted by Volker Heenes and the present author, supervised by Martin Mulsow. The images of the Strada volumes in Gotha are accessible through the Digitale Historische Bibliothek Erfurt-Gotha: https://archive .thulb.uni-jena.de/ufb/servlets/solr/ufb2?q=Strada.; selected images and texts are entered in the Documents file of the Census, where they are related to existing ancient coins in the Monuments file; they are planned to become publicly accessible by the end of 2018 . 
This also holds for most of my own earlier publications on Strada, which deal with specific themes: Strada's relations with his patrons, especially at the Imperial court, his activities as a collector and dealer in art and antiquities, his antiquarian studies, and his interest in architecture..$^{102}$

The present book may fill some of the lacunae signalled above, but it is primarily an attempt towards an all-round biography of Jacopo Strada. First it will give as complete an overview as possible of the many different activities in which he engaged during his long life. Second, its aim is to analyse each of these activities in their context, or rather contexts: context of place and context of time; context of traditions continued, and of innovations introduced by Strada and his contemporaries. Most important, Strada's activities will be considered not as separate or isolated events, but will be studied in relation to one another. One question will be whether it is possible to reduce the manifold and at first sight disparate aspects of Strada's life and career to something approaching a meaningful and coherent order. Can a consistent pattern be discovered in his activities that would allow us to add them up to something approaching a distinct profession? And if so, was such a profession more than just a private concept present in Strada's mind, or can it be considered a more or less generally recognized trade, craft or calling?

If so, the name of that profession is clearly and proudly indicated on the title pages of all of Strada's books and presentation manuscripts, and was never omitted from his signature in his letters to his patrons: Antiquario in Italian, Antiquarius in Latin. As we have seen, in English these terms can be translated by 'antiquarian', 'antiquary', or even 'archaeologist'. In my text I generally prefer to use the term 'antiquary', as being the most neutral and least anachronistic. ${ }^{103}$ A comparative study of other individuals indicated or indicating themselves with this appellation is no part of this study, but I hope the presentation of the data of Strada's career in future will help to answer that question by making such a comparison feasible.

Considering the certain data on Strada's life in their mutual interdependence and in their context will allow me to draw some conclusions not warranted by the isolated facts alone. The extant documents, which are listed in

102 Cf. bibliography, s.v. Jansen.

103 But I prefer not to be dogmatic about it, in this following Arnaldo Momigliano, who in his ground-breaking article used both 'antiquary' and 'antiquarian' without explicit distinction (Momigliano 1950). Bernd Kulawik drew my attention to Strada's use of the indication 'EK MOY $\Sigma$ EIOY IAK $\Omega B O Y$ TOY $\Sigma$ TPA $\triangle$ AI MANTOANOY KAI $\Sigma$ APON APXAIO $\Lambda$ OГOY' on the (Greek) title page of the first volume of the album depicting and describing (Greek) Roman Provincial Imperial coins in Vienna (ÖNB-HS 9416), and to the significance of this possibly early use of that term. 
the chronological list of sources inserted at the end of this book, allow me to sketch a truthful, though incomplete map of his career, to define the location and the size of the remaining white spots on this map, and in some cases provide at least an inkling of what may be found there. One of the white spots is, for instance, the commercial side of Strada's workshop: as for almost all of his contemporaries, his private accounts have not been preserved, though it is clear that particularly in his case the information these would provide would have been invaluable. Another white spot is the role Strada played with regard to the artistic patronage at the court of Maximilian II, his most important patron. It will be argued that the lack of conclusive evidence here is largely caused by the fact of Strada's personal presence at court, where his influence was chiefly exerted through direct oral consultation with his patron and with other courtiers, as well as with the artists and scholars involved in the Emperor's projects.

The next step is to fill in the white spots as far as possible, by means of a process of reasonable conjecture. It is, for instance, rather likely that Strada was paid a substantial salary as a court architect because he was expected to actually contribute to the building projects at court. We may reasonably assume that he did so, even though we do not exactly know what he did, when and for which project. Setting out from that assumption, a detailed examination of what we do know factually about Strada as an architect and designer, about the building projects at court, and about possible competitors, will help us to define his general role more clearly, and possibly even allow us to assign specific tasks or commissions to him. Likewise, it is very unlikely that Wenzel Jamnitzer would have chosen Strada as a designer for the prestigious commission Archduke Ferdinand gave him, if he did not know Strada personally, and had not had previous experience of his competence. We may reasonably attempt to reconstruct their collaboration on the basis of further documentary and stylistic evidence. Though such reasonable conjectures are bound to remain hypotheses which for lack of explicit data may never be proved conclusively, they nonetheless carry us as far into the white spots in Strada's life, and as close to the historical truth, as we will ever be able to get.

By spinning such loose fibres, fragments of factual evidence, into threads, and weaving these uneven threads together, I hope to produce a fabric thathowever loosely-knit and full of holes - will be strong enough to support some definite conclusion about Strada's profession, his character, and his place in the cultural history of his time. The most important of these will be an estimate of his influence on the development of ideas and taste in the regions where he was active, in particular his role as an agent in the transmission of the ideas and artistic forms of the Italian Renaissance across the Alps. 